\title{
Redescription of Astyanax obscurus (Hensel, 1870) and A. laticeps (Cope, 1894) (Teleostei: Characidae): two valid freshwater species originally described from rivers of Southern Brazil
}

\author{
Vinicius A. Bertaco ${ }^{1}$ and Carlos A. S. de Lucena ${ }^{2}$
}

Astyanax obscurus and A. laticeps are redescribed. Both species were originally described from the laguna dos Patos system, Rio Grande do Sul, Brazil. The deepest and most robust body area close to the middle of the pectoral fins length, robust head, snout short and abrupt, body depth smaller than $41 \%$ of SL, reduced number of branched anal-fin rays, presence of one or two humeral spots, and a dark midlateral body stripe extending to the tip of the middle caudal-fin rays include both in the $A$. scabripinnis species complex. The presence of two humeral spots ( $v s$. one), external row of the premaxillary with pentacuspid teeth (vs. tricuspid), and absence of bony hooks in all fins in males (vs. presence in anal and ventral fins) distinguish $A$. obscurus from A. laticeps. These species distinguish from species of this complex by meristic and morphometric characters and color pattern. An identification key for the species of genus occurring in the laguna dos Patos system is presented.

Astyanax obscurus e A. laticeps são redescritas. Ambas espécies foram descritas do sistema da laguna dos Patos, Rio Grande do Sul, Brasil. A maior altura e robustez do corpo na vertical que passa pela metade do comprimento das nadadeiras peitorais, cabeça robusta, focinho curto e abrupto, altura do corpo menor que $41 \%$ do $\mathrm{CP}$, reduzido número de raios ramificados na nadadeira anal, presença de uma ou duas manchas umerais e barra escura horizontal na linha média do corpo estendendo-se até a extremidade dos raios da nadadeira caudal permitem sua inclusão no complexo de espécies A. scabripinnis. A presença de duas manchas na região umeral (vs. uma única), fileira externa do pré-maxilar com dentes pentacuspidados ( $v s$. tricuspidados) e ausência de ganchos nas nadadeiras de exemplares machos (vs. presença nas nadadeiras anal e ventral) distinguem $A$. obscurus de A. laticeps. Estas espécies diferem das demais incluídas no complexo por caracteres merísticos e morfométricos e padrão de colorido. É fornecida uma chave de identificação para as espécies do gênero ocorrentes no sistema da laguna dos Patos.

Key words: Neotropical fish, Taxonomy, Astyanax scabripinnis species complex, Laguna dos Patos system.

\section{Introduction}

Bertaco \& Lucena (2006) included both Astyanax obscurus (Hensel) and A. laticeps (Cope) in the A. scabripinnis species complex, a group previously proposed by Moreira-Filho \& Bertollo (1991), and further discussed by Bertaco \& Malabarba (2001). According to Bertaco \& Lucena (2006), the species of the A. scabripinnis complex possess the deepest and most robust body area close to the middle of the length of the pectoral fins, a robust head, snout short and abrupt, body depth smaller than $41 \%$ of SL (mean $30-33 \%$ of SL), reduced number of branched anal-fin rays (13-23, usually $17-18$, rarely 22 or 23 ), presence of one or two humeral spots, and a dark midlateral body stripe extending to the tip of the middle caudal-fin rays.

Hensel (1870) described Tetragonopterus obscurus as a new species, based on three specimens from rio "Cadea" (Cadeia) above a large waterfall, in Rio Grande do Sul State. Soon after, Steindachner (1876) listed T. obscurus as a junior synonym of T. fasciatus Cuvier, 1819. Afterward, Eigenmann (1910) transferred most species of Tetragonopterus to the genus Astyanax and listed T. obscurus as a junior synonym of Astyanax bimaculatus (Linnaeus, 1758). Later, Malabarba (1989) listed T. obscurus as a synonym of "Astyanax aff. fasciatus (Cuvier)". Lima et al. (2003) listed A. obscurus as a valid species, without any comment. Recently, Melo \& Buckup (2006) examined the types of $A$. obscurus and confirmed the proposition of Lima et al. (2003).

Tetragonopterus laticeps was described by Cope (1894) from Rio Grande do Sul State. Subsequently, Eigenmann (1910, 1921) listed Astyanax laticeps as a subspecies of $A$. scabripinnis (Jenyns, 1842), and in 1927, proposed five subspecies for A. scabripinnis, including A. scabripinnis laticeps. Later, Malabarba (1989) maintained the taxonomic status of this species as previously designated by Eigenmann. Astyanax laticeps was considered for decades as a subspecies of A. scabripinnis. However, Bertaco \& Malabarba (2001)

${ }^{1}$ Universidade Federal do Rio Grande do Sul, Departamento de Zoologia, Laboratório de Ictiologia, Av. Bento Gonçalves, $9500,91501-970$ Porto Alegre, RS, Brazil.vbertaco@gmail.com

${ }^{2}$ Setor de Ictiologia, Museu de Ciências e Tecnologia, Pontifícia Universidade Católica do Rio Grande do Sul. Av. Ipiranga, 6681, CP 1491, 90619-900 Porto Alegre, RS, Brazil. lucena@pucrs.br 
examined the types of $A$. laticeps and concluded that it is a valid species, a proposition subsequently followed by Lima et al. (2003) and Rosa et al. (2009).

Both species were originally described from the Atlantic coastal drainages of Rio Grande do Sul State, Brazil. Astyanax obscurus from rio Cadeia (rio Jacuí drainage) and A. laticeps have their type locality restricted to the laguna dos Patos system by Malabarba (1989). The original descriptions are imprecise, and their diagnostic characters were never properly investigated. More recently, A. laticeps was recorded from a limited portion of laguna dos Patos system by Azpelicueta \& Loureiro (2009). Herein, we redescribe $A$. obscurus and $A$. laticeps based on a new and large series of specimens.

\section{Material and Methods}

The specimens examined are deposited in the Academy of Natural Science, Philadelphia (ANSP), Museo Argentino de Ciencias Naturales Bernardino Rivadavia, Buenos Aires (MACN), Museu de Ciências e Tecnologia, Pontifícia Universidade Católica do Rio Grande do Sul, Porto Alegre (MCP), Facultad de Ciencias Naturales y Museo, Universidad Nacional de La Plata, La Plata (MLP), Museu de Ciências Naturais, Universidade Católica de Pelotas, Pelotas (MUCP), Departamento de Zoologia, Universidade Federal do Rio Grande do Sul, Porto Alegre (UFRGS), and Museum fur Naturkunde der Humboldt Universität, Berlin (ZMB).

Counts were taken as described by Fink \& Weitzman (1974), with the exception of the number of scale rows below the lateral line, which followed Bertaco \& Lucena (2006). Counts of vertebrae, supraneurals, gill-rakers on the first arch, teeth, and procurrent caudal-fin ray counts were taken from cleared and stained (c\&s) specimens prepared according to Taylor \& van Dyke (1985). Tooth counts were also taken in all specimens included in the tables. Vertebral counts included the four vertebrae of the Weberian apparatus, and the terminal centrum counted as a single element. In the descriptions, an asterisk indicates counts of the type series. Lower and upper jaws of c\&s specimens were prepared for SEM (scanning electron microscopy) in the Centro de Microscopia e Microanálises, CEMM (PUCRS), and Centro de Microscopia Eletrônica, CME (UFRGS).

Measurements were taken point to point with a caliper on the left side of specimens whenever possible. Measurements are expressed as percentage of standard length (SL) except for subunits of the head, which are recorded as percents of head length (HL). In the material examined, the catalog number is followed by the total number of the lot and, in parentheses, the number of specimens counted and measured and respective length range. In cases without parentheses, the range length corresponds to the smallest and largest specimens of the lot.

The laguna dos Patos system includes laguna dos Patos, laguna Mirim and all their tributaries, and the rio Tramandaí drainage includes rio Maquiné and rio Três Forquilhas, according to Malabarba (1989) and Malabarba \& Isaia (1992), respectively.
The geographic variation of $A$. laticeps was investigated considering the following main drainages (listed from south to north): laguna dos Patos system, rio Tramandaí drainage, rio Mampituba, rio Tubarão, rio Itajaí-Açu, rio Itapocu, and rio Cubatão Norte (Santa Catarina). The samples were analyzed in each one and the sex determined. As no difference was found, the specimens were combined in respective drainages. The specimens from rio Uruguay drainage, coastal drainages from Uruguay, and coastal rivers of Paraná State were not considered for multivariate analysis due to their reduced number and/or size of specimens.

The analysis of geographic variation of the counts of $A$. laticeps was performed with SigmaPlot 2.0 for Windows 95 and SigmaStat 2.0 for Windows 95. The measures were performed by Principal Component Analysis (PCA) discussed by Bookstein et al. (1985:101), and using the software PAST 1.8 (Hammer \& Harper, 2003). Basic descriptive statistics and statistical tests for meristic data follow Weitzman \& Malabarba (1999).

\section{Results}

\section{Astyanax obscurus (Hensel, 1870) Figs. 1-4a}

Tetragonopterus obscurus Hensel, 1870:86-87. Type locality: Rio Cadea [rio Cadeia, tributary of rio Caí, rio Jacuí drainage] above large waterfall.

Astyanax obscurus. -Lima et al., 2003:11 (valid species). Melo \& Buckup, 2006:50 (morphometric and meristic data of the syntypes).

Diagnosis. Astyanax obscurus belongs to the A. scabripinnis species complex and is distinguished from most species of this complex (except $A$. burgerai, A. leonidas, A. ojiara and A. rivularis), by the shape of the first humeral spot: vertically elongate with upper portion wider, located over third to fifth vertical series of scales and extending over 2 to 3 horizontal series of scales above of the lateral line, lower portion narrow ( 1 to 2 scales pigmented), and extending over 1 to 2 horizontal series of scales below the lateral line ( $v s$. upper and lower portions of similar width or upper portion slightly wider). Astyanax obscurus differs from A. burgerai by the number of lateral line scales (37-39 vs. 31-34), number of scale rows between lateral line and pelvic fin origin (4-5vs. 3), and absence of bony hooks in the anal fin of males; from A. leonidas by the number of lateral line scales 37-39, usually 38 (vs. 35-37, usually 35-36), number of total vertebrae (36-38 vs. 32-33), orbital diameter $25.7-34.6 \%$ ( $v s .34 .3-41.2 \%$ of HL), and absence of bony hooks in fins in males; from A. ojiara by maxillary tooth tricuspid (vs. heptacuspid), and absence of bony hooks in all fins and on axillary scale in males; from $A$. rivularis by the number of the lateral line scales (37-39vs. 33-35), maxillary tooth tricuspid ( $v s$. pentacuspid), and absence of bony hooks on anal and pelvic fin rays. Astyanax obscurus differs from three 
sympatric species of the $A$. scabripinnis complex by first humeral spot shape (horizontally elongate humeral spot with a narrow anteroventral downward extension in A. laticeps, and wedge shape uniform in A. brachypterygium and A. cremnobates), and by the absence of bony hooks in pelvic and anal fin rays of males (vs. presence). The holotype, only specimen known of A. scabripinnis, is relatively well preserved, but has completely lost its color pattern, which preclude a comparison of humeral spot form with A. obscurus. Astyanax obscurus differs from $A$. scabripinnis by the number of predorsal scales (11-14 vs. 9), interorbital width (28.2-33.9 vs. 40.7\% of HL), and by anal fin base length (20.4-24.0 vs. $30.2 \%$ of SL).

Description. Morphometric data summarized in Table 1. Body compressed and elongate, with greatest body depth anterior to dorsal-fin origin. Dorsal profile of head straight or slightly convex from posterior nostril to tip of supraoccipital spine. Dorsal body profile convex from tip of supraocciptal spine to base of last dorsal-fin ray; straight from latter point to adipose fin origin. Ventral profile of body slightly convex from vertical through posterior nostril to pectoral fin origin, nearly straight to anal-fin origin, and posterodorsally slanted along anal fin base. Caudal peduncle elongate, nearly straight to slightly concave in the dorsal and ventral margins.

Snout rounded from margin of upper lip to vertical through anterior nostrils. Head small. Mouth terminal, lower jaw slightly longer than upper jaw. Maxilla extending posteriorly to vertical through anterior margin of orbit, slightly curved, aligned at angle of approximately 45 degrees to longitudinal body axis. Maxilla slightly widened anteroposteriorly.

Two tooth rows in premaxilla; outer row with three to five $\left(4-5^{*}\right)$ pentacuspid teeth, central cusp longer; inner row with

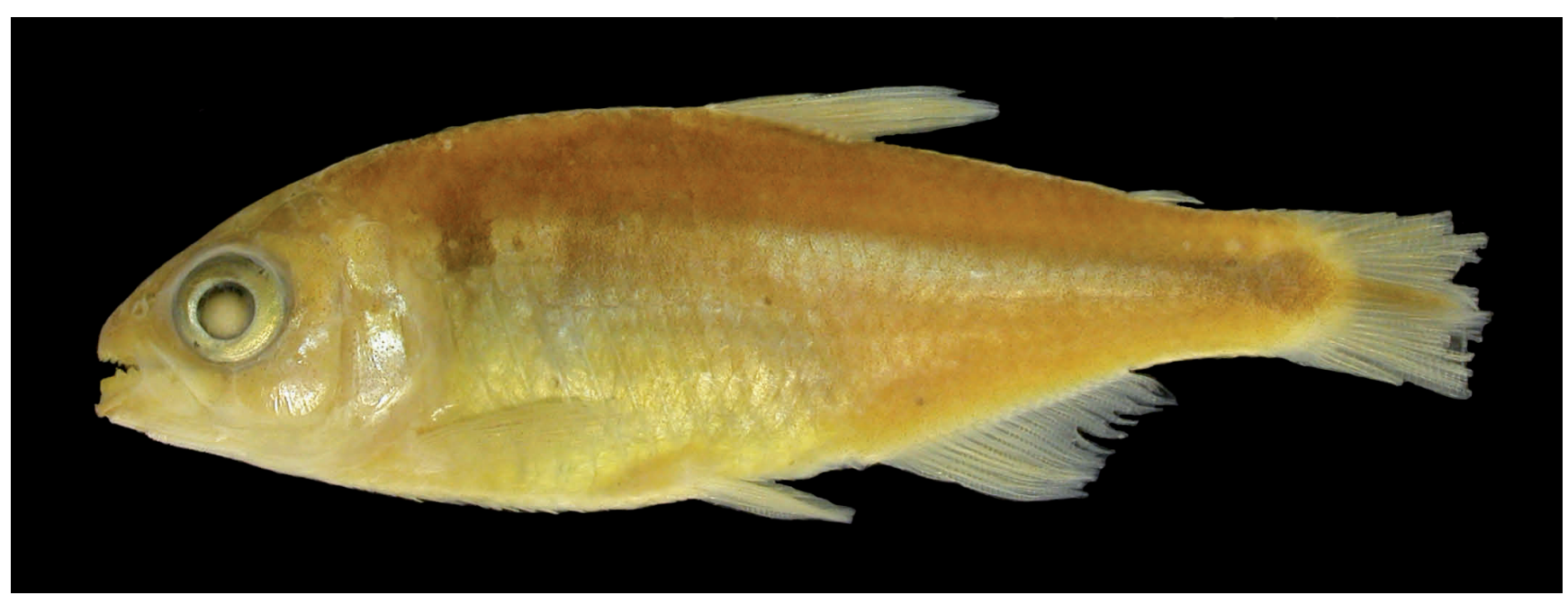

Fig. 1. Astyanax obscurus, ZMB 7478, syntype, $57.8 \mathrm{~mm}$ SL, rio Cadeia above of the large waterfalls, Santa Maria do Herval, Rio Grande do Sul, Brazil.

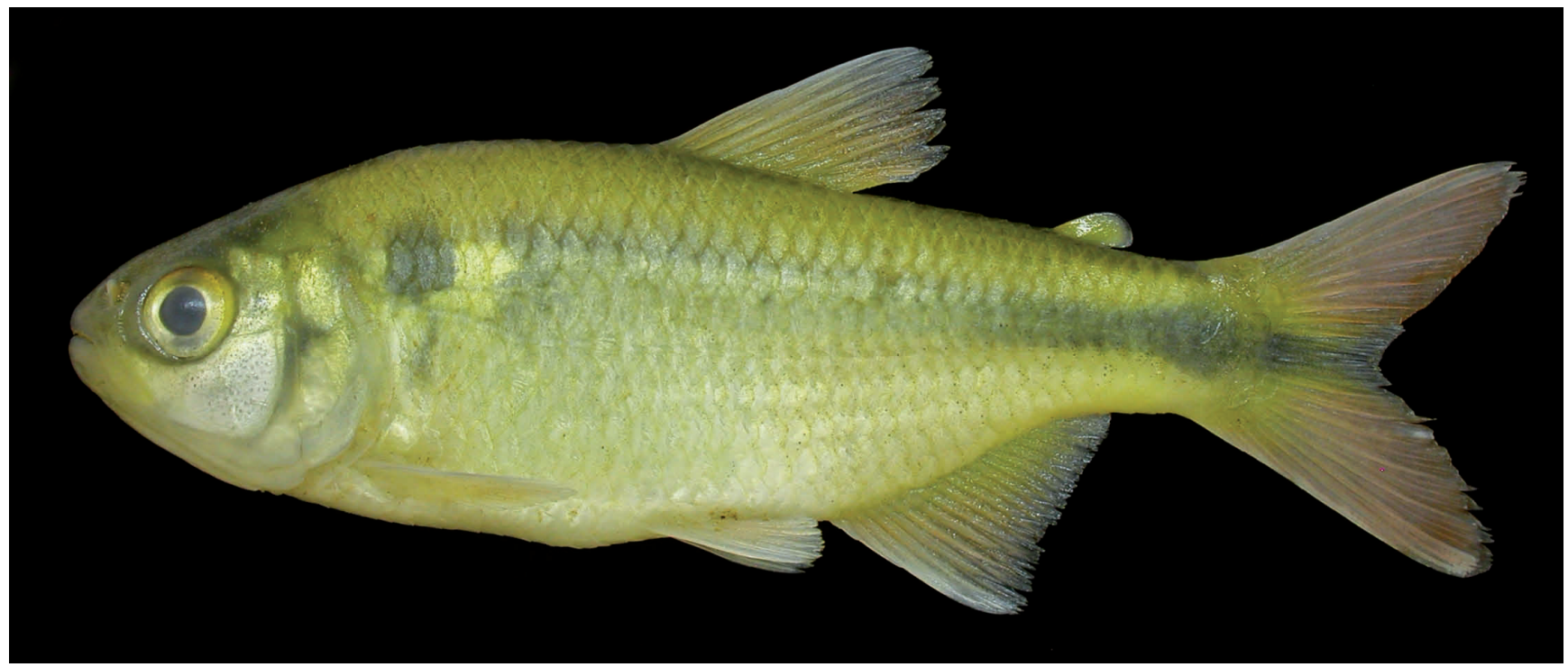

Fig. 2. Astyanax obscurus, MCP 40000, $59.2 \mathrm{~mm}$ SL, rio Cadeia above the large waterfalls, Santa Maria do Herval, Rio Grande do Sul, Brazil. 
five teeth, gradually decreasing in length from the first to fourth, last distinctly smaller, with five to seven cusps; central cusp twice as long and broad as others cusps. Maxilla with one* (rarely two) teeth, one to three cusps, with central cusp longer. Three to four anteriormost dentary teeth larger, with five or seven cusps, followed by one medium-sized teeth with three to five cusps, and four or six teeth with one to three cusps. Central cusp in all teeth two to three times as long and broad as other cusps. All cusp tips slightly curved posteriorly towards inside mouth (Fig. 3).

Dorsal-fin rays ii,9 (ii,9-10*, one specimen with ii, $11, \mathrm{n}=$ 28); first unbranched ray approximately half length of second ray. Distal margin of dorsal fin nearly straight to somewhat convex. Dorsal fin origin approximately at middle of SL. Adipose fin approximately at vertical through last anal-fin ray insertion. Anal-fin rays iii-v, 16-21 (18-19*, one specimen with 15 , mean $=18.3, n=28$ ). First unbranched ray normally only apparent in c\&s specimens. Anal fin profile smoothly concave. Anal fin origin posterior to vertical through base of last dorsal-fin ray. Pectoral-fin rays i,11-13 (i,12-13*, mean = $11.7, \mathrm{n}=28)$. Pectoral-fin tip reaching one or two scales before vertical through pelvic-fin insertion. Pelvic-fin rays i,6-7 (i,7*, $\mathrm{n}=28$ ). Pelvic fin origin slightly anterior to vertical through dorsal-fin origin. Pelvic-fin tip trespasses the genital opening but not reach the anal-fin origin. Caudal fin forked, lobes similar in size, $19 *$ principal rays. Dorsal procurrent rays 1011 , and ventral procurrent rays 8-10 $(n=6)$.

Lateral line complete with $37-39$ scales $\left(37-39^{*}\right.$, mean $=38$, $\mathrm{n}=28$ ). Scale rows between dorsal-fin origin and lateral line 5$6 *($ mean $=5.9, \mathrm{n}=28) ; 4-5 *$ scale rows between lateral line and pelvic-fin origin $($ mean $=4.5, \mathrm{n}=28)$. Predorsal scales 11 $14\left(11-12^{*}\right.$, mean $\left.=12.2, \mathrm{n}=28\right)$ arranged in regular series. Scale rows around caudal peduncle $14 *-16($ mean $=14.3, \mathrm{n}=$ 28). Axillary scale on pelvic fin origin extends posteriorly covering 2-3 scales. Scale sheath along anal fin base 6-9 scales, in single series, covering base of anteriormost rays.

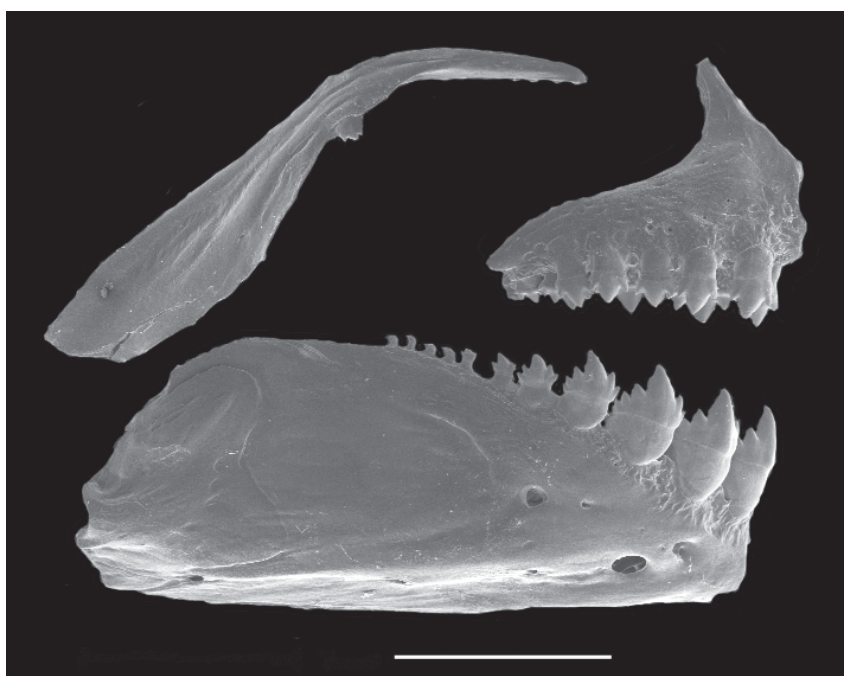

Fig. 3. Astyanax obscurus, MCP 26125, $65.5 \mathrm{~mm}$ SL. SEM image of upper and lower jaws, right side. Scale bar $=2 \mathrm{~mm}$.
Precaudal vertebrae 17-19; caudal vertebrae 18-19; total vertebrae 36-38 $(n=6)$. Supraneurals 5-6 $(n=6)$. Gill-rakers upper branch 6-8 $($ mean $=6.7, \mathrm{n}=30)$, lower branch 11-14 $($ mean $=12.7, \mathrm{n}=30)$.

Color in alcohol. Dorsal and dorsolateral portions of head and body dark brown. Dark chromatophores scattered on lateral portion of head, more densely concentrated on snout and anterior border of eye. Dorsal portion of body densely pigmented in larger specimens. Body with black, midlateral stripe extending from the second humeral spot to caudal fin base; faint dark pigmentation present on middle caudal-fin rays. Midlateral body stripe expanded dorsally and ventrally to caudal fin base, forming small caudal spot. Two humeral spots. Anterior one, conspicuous, vertically elongate with superior portion wider, located over third to fifth vertical series of scales, extending over 2 to 3 horizontal series of scales above lateral line; inferior portion of spot narrow (1 to 2 scales pigmented), extending over 1 to 2 horizontal series of scales below lateral line. Second humeral spot large, occasionally faint, not ventrally surpassing lateral line,

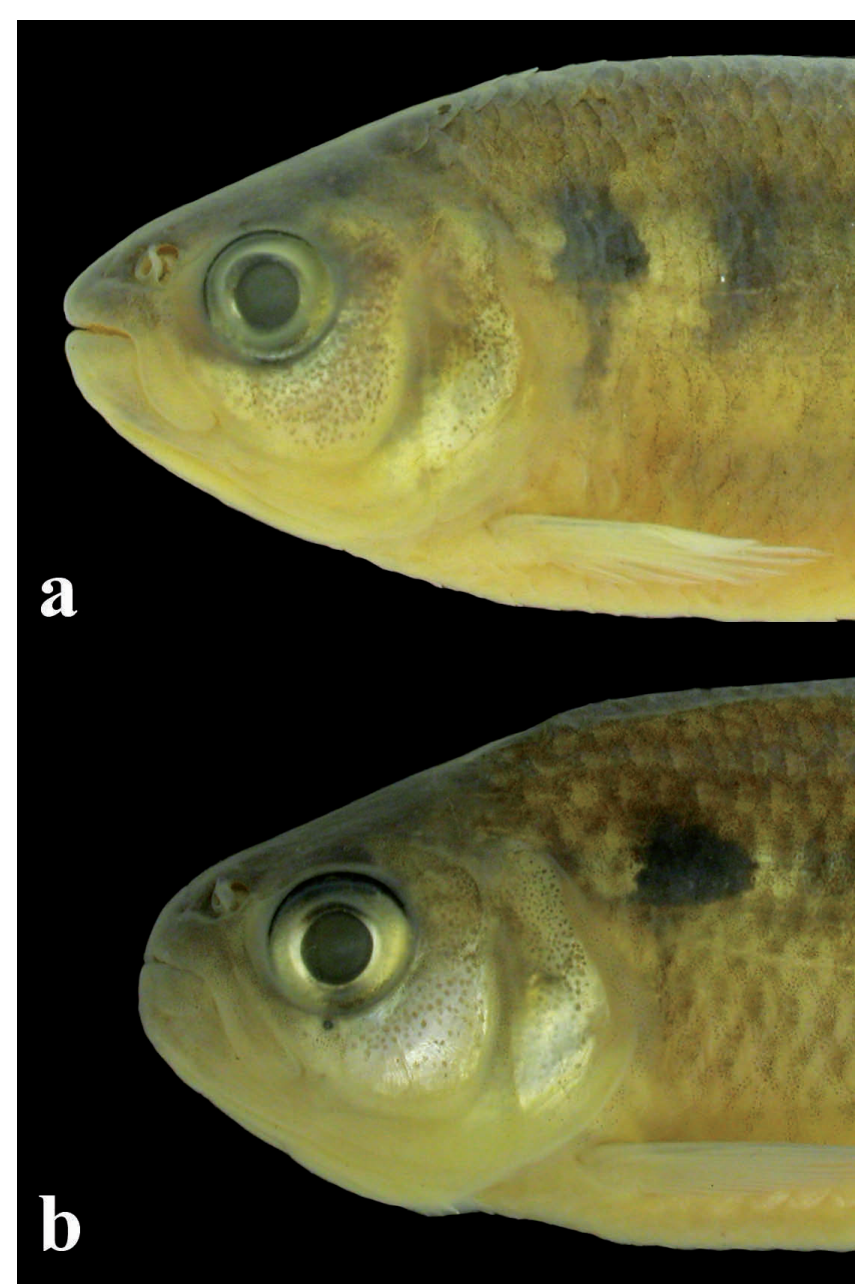

Fig. 4. Lateral view of left side of anterior region showing humeral spots of (a) Astyanax obscurus, MCP 26125, 75.6 mm SL, and (b) Astyanax laticeps, MCP 26127, $71.1 \mathrm{~mm} \mathrm{SL}$. 
extending over 3 horizontal series and 2 to 3 vertical series of scales (Figs. 2 and 4a). Region between spots pale. In specimens smaller than $28.0 \mathrm{~mm}$ SL superior portion of first humeral spot lightly larger than inferior portion, second humeral spot can be absent. Fins with dispersed dark chromatophores. Specimens a few days fixed in formalin (MCP 40000) with overall body coloration greenish and all fins red and yellowish pigmented.

Sexual dimorphism. Secondary sexual characters were not found on examined specimens. Testes were observed in one dissected c\&s specimen (MCP 26125, $67.7 \mathrm{~mm} \mathrm{SL}$ ). Gill glands (Burns \& Weitzman, 1996) were not found on first gill arch in all specimens.

Distribution. Astyanax obscurus is known from the upper and middle rios Caí and Taquari-Antas, rio Jacuí drainage, Rio Grande do Sul, Brazil (Fig. 5).

Ecological notes. The rio Cadeia at the locality where were caught the syntypes is a fast-flowing clear water river until $1.0 \mathrm{~m}$ deep and about $10-15 \mathrm{~m}$ wide. The locality is situated upstream of the natural waterfall with about $125 \mathrm{~m}$ highest named by Cascata do Herval, around 370 m a.s.1., 29²9'59'S $50^{\circ} 56^{\prime} 49^{\prime \prime} \mathrm{W}$; the bottom consists of mud, stones, and rocks and with moderately riparian vegetation. Topotypes of Astyanax obscurus were collected with A. laticeps, Bryconamericus iheringii, Crenicichla punctata, Hyphessobrycon luetkenii, Phalloceros caudimaculatus, and Rineloricaria cadeae.

Material examined. Syntypes. ZMB 7478, 3 (3, 46.5-57.8 mm SL), rio Cadea [Cadeia] above large waterfall, [Santa Maria do Herval], Rio Grande do Sul, Brazil, 1863-1866, R. F. Hensel. Non-types:

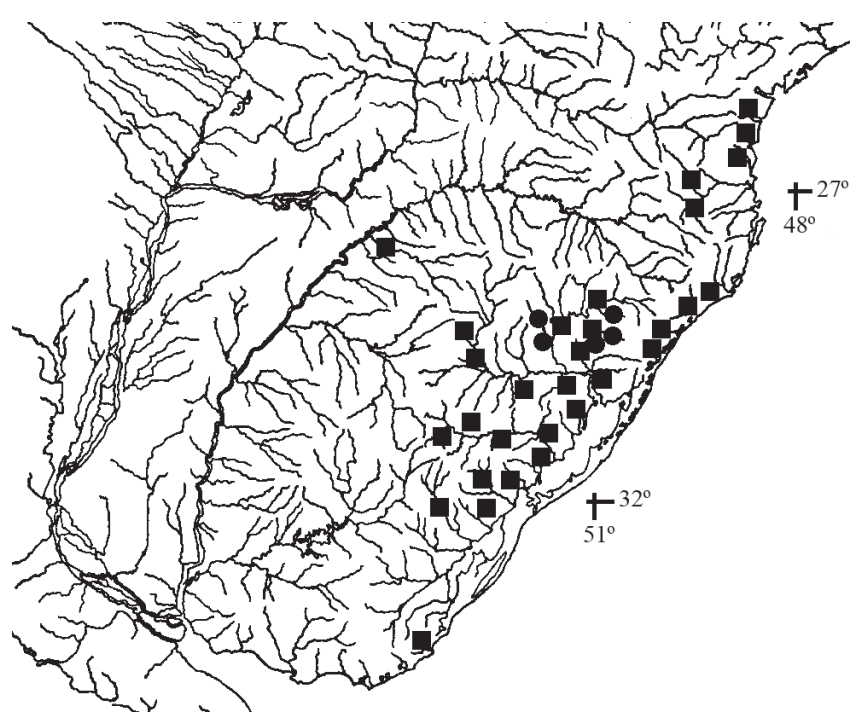

Fig. 5. Map of southern Brazil and Uruguay, showing the distribution of examined material of Astyanax obscurus (circles), and Astyanax laticeps (squares). Some symbols represent more than one lot or locality.

Brazil: Rio Grande do Sul: laguna dos Patos system: rio Jacuí drainage: MCP 11145, 28, 31.3-83.3 mm SL, arroio Dizimeiro on the road between São Francisco de Paula and Lageado Grande. MCP 15198, 5, 69.1-83.8 mm SL; MCP 15396, 13 (12, 65.0-82.8 mm SL), tributary of arroio Feitoria, Dois Irmãos. MCP 17493, 10, (10, 41.7$88.3 \mathrm{~mm} \mathrm{SL}$ ), tributary of arroio Castelhano, rio Taquari drainage, Venâncio Aires. MCP 20017, 3, 43.4-73.6 mm SL, arroio Feitoria, Sapiranga. MCP 20040, 13 (10, 38.2-47.0 mm SL), arroio Feitoria, Sapiranga. MCP 21331, 4, 65.4-74.2 mm SL, arroio Feitoria, Sapiranga. MCP 21542, 6 (6, 58.3-76.3 mm SL), stream about $7 \mathrm{~km}$ North of Barros Cassal, tributary of rio Fão, Barros Cassal. MCP 25686, 28, 29.0-57.9 mm SL, stream about $7 \mathrm{~km}$ North of Barros Cassal, tributary of rio Fão, Barros Cassal. MCP 21567, 5 (5, 43.4-61.9 mm

Table 1. Morphometric data of Astyanax obscurus: syntypes (ZMB 7478, $\mathrm{n}=3$ ), and non-type specimens from rio Cadeia, tributary of rio Caí (A, $\mathrm{n}=21$ ), and from rio das Antas, rio Jacuí drainage (B, $\mathrm{n}=33$ ); and Astyanax laticeps: holotype (ANSP 21852), and paratypes (ANSP 21743, $\mathrm{n}=4$ ), Rio Grande do Sul, Brazil.

\begin{tabular}{|c|c|c|c|c|c|c|c|c|c|}
\hline & \multicolumn{6}{|c|}{ A. obscurus } & \multicolumn{3}{|c|}{ A. laticeps } \\
\hline & \multicolumn{2}{|c|}{ Syntypes } & \multicolumn{2}{|c|}{$\mathrm{A}$} & \multicolumn{2}{|c|}{$\mathrm{B}$} & \multirow{2}{*}{ Holot. } & \multicolumn{2}{|c|}{ Paratypes } \\
\hline & Range & Mean & Range & Mean & Range & Mean & & Range & Mean \\
\hline $\begin{array}{l}\text { Standard length }(\mathrm{mm}) \\
\text { Percents of Standard length }\end{array}$ & $46.5-57.8$ & 53.1 & $39.3-76.4$ & 61.8 & $42.1-88.3$ & 65.7 & 54.1 & $38.0-50.8$ & 44.1 \\
\hline Predorsal distance & $55.1-57.2$ & 56.0 & $51.9-55.8$ & 54.0 & $51.9-56.1$ & 54.2 & 56.0 & $56.2-58.2$ & 57.4 \\
\hline Prepelvic distance & $50.1-54.7$ & 52.8 & $50.6-54.4$ & 52.4 & $50.3-55.0$ & 52.0 & 50.8 & $50.3-51.2$ & 50.7 \\
\hline Prepectoral distance & $26.5-28.9$ & 28.0 & $26.8-29.2$ & 28.1 & $25.0-28.4$ & 26.7 & 29.5 & 28.5-30.4 & 29.3 \\
\hline Preanal distance & $66.0-69.8$ & 68.1 & $65.3-70.3$ & 68.4 & $67.0-70.8$ & 68.4 & 69.9 & $69.0-73.7$ & 70.6 \\
\hline Depth at dorsal-fin origin & $32.7-34.6$ & 33.9 & $31.6-37.2$ & 34.5 & $33.6-40.8$ & 36.7 & 38.8 & $35.3-40.6$ & 37.9 \\
\hline Caudal-peduncle depth & $11.5-12.1$ & 11.8 & $12.2-13.6$ & 12.8 & $11.2-13.2$ & 12.3 & 14.2 & 13.4-14.4 & 14.0 \\
\hline Caudal-peduncle length & $14.4-15.8$ & 15.3 & 14.4-17.0 & 15.8 & $12.4-16.3$ & 14.2 & 11.5 & $9.2-11.9$ & 10.8 \\
\hline Anal-fin base length & $20.6-22.8$ & 21.7 & $20.4-24.0$ & 22.1 & $21.2-25.6$ & 23.3 & 29.1 & $25.7-27.4$ & 26.3 \\
\hline Dorsal-fin length & $18.2-24.8$ & 22.6 & $23.5-27.2$ & 25.5 & $21.7-26.3$ & 23.8 & - & 26.4-28.1 & 27.0 \\
\hline Pelvic-fin length & $14.6-16.3$ & 15.5 & $14.3-16.6$ & 15.3 & $14.1-17.0$ & 15.5 & 17.1 & $16.9-18.1$ & 17.6 \\
\hline Pectoral-fin length & $21.7-23.1$ & 22.4 & $20.4-23.5$ & 22.1 & $19.5-22.6$ & 20.8 & 20.5 & 22.3-23.4 & 22.7 \\
\hline $\begin{array}{l}\text { Head length } \\
\text { Percents of Head length }\end{array}$ & $28.0-29.8$ & 29.0 & $26.7-29.1$ & 28.1 & $25.2-29.6$ & 27.2 & 29.0 & $29.3-30.0$ & 29.6 \\
\hline Snout length & $24.9-26.0$ & 25.4 & 23.4-28.5 & 26.1 & $23.5-28.1$ & 25.3 & 24.9 & $25.4-26.2$ & 25.8 \\
\hline Upper jaw length & $39.2-41.1$ & 40.4 & $38.5-42.7$ & 41.0 & $37.7-44.4$ & 41.0 & 46.4 & 43.4-45.7 & 44.6 \\
\hline Orbital diameter & $31.0-33.9$ & 32.2 & 28.2-32.9 & 30.3 & $25.7-34.6$ & 30.7 & 29.4 & 29.1-31.7 & 30.5 \\
\hline Interorbital width & $26.4-28.6$ & 27.4 & $28.1-32.5$ & 30.1 & $27.7-34.0$ & 29.9 & 36.8 & $36.5-37.5$ & 36.9 \\
\hline
\end{tabular}


SL), stream on the road beetwen Barros Cassal and Gramado Xavier, Gramado Xavier. MCP 21730, 12 (8, 51.3-83.0 mm SL), stream between Dois Irmãos and Morro Reuter, locality of Travesso, Dois Irmãos. MCP 22304, 4, 31.5-82.8 mm SL, headwater of rio Lageado Grande, about $1 \mathrm{~km}$ of Várzea do Cedro, Lageado Grande. MCP 26125, 14 (13, 35.2-79.8 mm SL; 2 c\&s, 65.5-67.7 mm SL), arroio Cadeia in the Jacaré beach, tributary of rio Caí, Santa Maria do Herval. MCP 39999, 24, 19.9-32.3 mm SL, rio Cadeia about $3 \mathrm{~km}$ from Amizade beach, Santa Maria do Herval. MCP 40000, 43 (10, 33.5$60.4 \mathrm{~mm}$ SL; 4 c\&s, 33.5-53.7 mm SL), rio Cadeia in the Amizade beach, Vila Amizade, Santa Maria do Herval. MCP 40001, 11 (6, 34.3-45.0 mm SL), rio Cadeia across from Jacaré beach, Vila Cristo Rei, Santa Maria do Herval.

\section{Astyanax laticeps (Cope, 1894) Figs. 4b, 6-8}

Tetragonopterus laticeps Cope, 1894:89. Type locality: Rio Grande do Sul, Brazil (restricted to laguna dos Patos system by Malabarba, 1989:130).

Astyanax laticeps. -Fowler, 1906:348 (designation of the holotype). -Bertaco \& Malabarba, 2001:233 (valid species, morphometric and meristic data of the types).

Diagnosis. Astyanax laticeps belongs to the A. scabripinnis species complex and is distinguished from all species of this complex, except $A$. troya, by the presence of one horizontally elongate black humeral spot with a narrow anteroventral downward extension past the lateral line. Astyanax laticeps differs from A. troya by the presence of one humeral spot ( $v S$. two), one to three maxillary teeth with one to three cusps ( $v s$. one pentacuspid tooth), and the presence of bony hooks only on anal and pelvic fins ( $v s$. present in all fins, except pectoral fin of males). A similar oval humeral spot can be found in A.jacuhiensis (a sympatric species and member of the A. bimaculatus species group sensu Garutti, 1995). Astyanax laticeps differs from A. jacuhiensis by the absence of two bars in the humeral region, presence of a narrow anteroventral downward extension of the humeral spot past the lateral line, and one to three maxillary teeth (vs. maxillary teeth absent). Note the differences between A. laticeps and A. obscurus in the diagnosis above. Astyanax laticeps differs from the holotype of $A$. scabripinnis by the predorsal distance (49.4-55.7 vs. 57.7\% of SL), anal fin base length (21.3-28.7vs. $30.2 \%$ of SL), and pelvic fin length (14.3-21.8 vs. $22.1 \%$ of SL).

Description. Morphometric data summarized in Tables 1-2. Body compressed and elongate; greatest body depth usually anterior to dorsal-fin origin. Dorsal profile of head between vertical through posterior nostril and tip of supraoccipital spine straight. Dorsal body convex profile from tip of supraocciptal spine to base of last dorsal-fin ray; straight from latter point to adipose fin origin. Ventral profile of body slightly convex from vertical through posterior nostril to pelvic fin insertion, nearly straight from that point to anal fin origin, and posterodorsally slanted along anal fin base. Caudal peduncle elongate, nearly straight to slightly concave in the dorsal and ventral margins.

Snout rounded from margin of upper lip to vertical through anterior nostrils. Head small. Mouth terminal. Maxilla extending posteriorly to vertical through anterior margin of orbit, slightly curved, and aligned at an angle of approximately 45 degrees relative to longitudinal body axis. Maxilla slightly widened posteriorly.

Two tooth rows in premaxilla; outer row with four to five* tricuspid teeth with central cusp longer; rarely, the most lateral teeth with two additional very small cusps. Five teeth in inner premaxillary row; teeth gradually decreasing in length from first to fourth teeth with last tooth distinctly smaller: teeth with three to five cusps with central cusp twice as long and broad as other cusps; rarely, two most lateral cusps present, but visible only in c\&s specimens. Maxilla with one to three (two to three*) teeth with one to three cusps, with central cusp longest. Four anteriormost dentary teeth larger, with five cusps, followed by five to seven small teeth with one to three cusps. Central cusp in all teeth two to three times as long and broad as other cusps. All cusp tips slightly curved posteriorly towards inside mouth (Fig. 8).

Dorsal-fin rays ii,9* (two specimens with ii, 8 , and five with ii, $10, n=140$ ); first unbranched ray approximately half the length of second ray. Distal margin of dorsal fin nearly straight or slightly convex. Dorsal fin origin approximately at middle of SL. Adipose fin approximately at vertical through last anal-fin ray insertion. Anal-fin rays iii-v, 15-23 (18-21*, mean $=19.5, \mathrm{n}=$ 140). First unbranched ray normally only apparent in c\&s specimens. Anal fin origin posterior to vertical through base of last dorsal-fin ray. Pectoral-fin rays i,10-14 (i,11-12*, mean = $12.2, n=140)$. Pelvic-fin rays i, $7 *(n=140)$. Pelvic fin origin slightly anterior to vertical through dorsal fin origin. Caudal fin forked, lobes similar in size, 19* principal rays. Dorsal procurrent rays $11-13$, and ventral procurrent rays $10-11(\mathrm{n}=14)$.

Lateral line complete with $37-40$ scales $\left(37-38^{*}\right.$, mean $=$ $37.0, \mathrm{n}=125)$. Scale rows between dorsal fin origin and lateral line 6-8 $\left(6^{*}\right.$, mean $\left.=6.8, \mathrm{n}=136\right)$; 4-6 scale rows between lateral line and pelvic fin origin $\left(5^{*}\right.$, mean $\left.=5.2, \mathrm{n}=137\right)$. Predorsal scales 9-14 $\left(11-12^{*}\right.$, mean $\left.=11.0, \mathrm{n}=117\right)$ arranged in regular series. Scale rows around caudal peduncle 14-18 $\left(14-16^{*}\right.$, mean $\left.=16.8, \mathrm{n}=121\right)$. Axillary scale on pelvic fin origin extends posteriorly covering 2-3 scales. Scale sheath along anal fin base 6-14 scales, in single series, covering base of anteriormost rays.

Precaudal vertebrae 17-18; caudal vertebrae 17-19; total vertebrae 35-37 $(n=15)$. Supraneurals 5-7 $(n=15)$. Gill-rakers upper branch 6-10 $($ mean $=8.2, n=135)$, lower branch 11-16 $($ mean $=13.2, \mathrm{n}=135)$.

Color in alcohol. Dorsal and dorsolateral portions of head and body dark brown. Dark chromatophores scattered on lateral portion of head, more densely concentrated on snout and anterior border of eye. Dorsal portion of body densely pigmented in larger specimens. Scales midlateral and below the lateral line bordered with dark brown chromatophores forming reticulate pattern. Body with black, midlateral stripe 


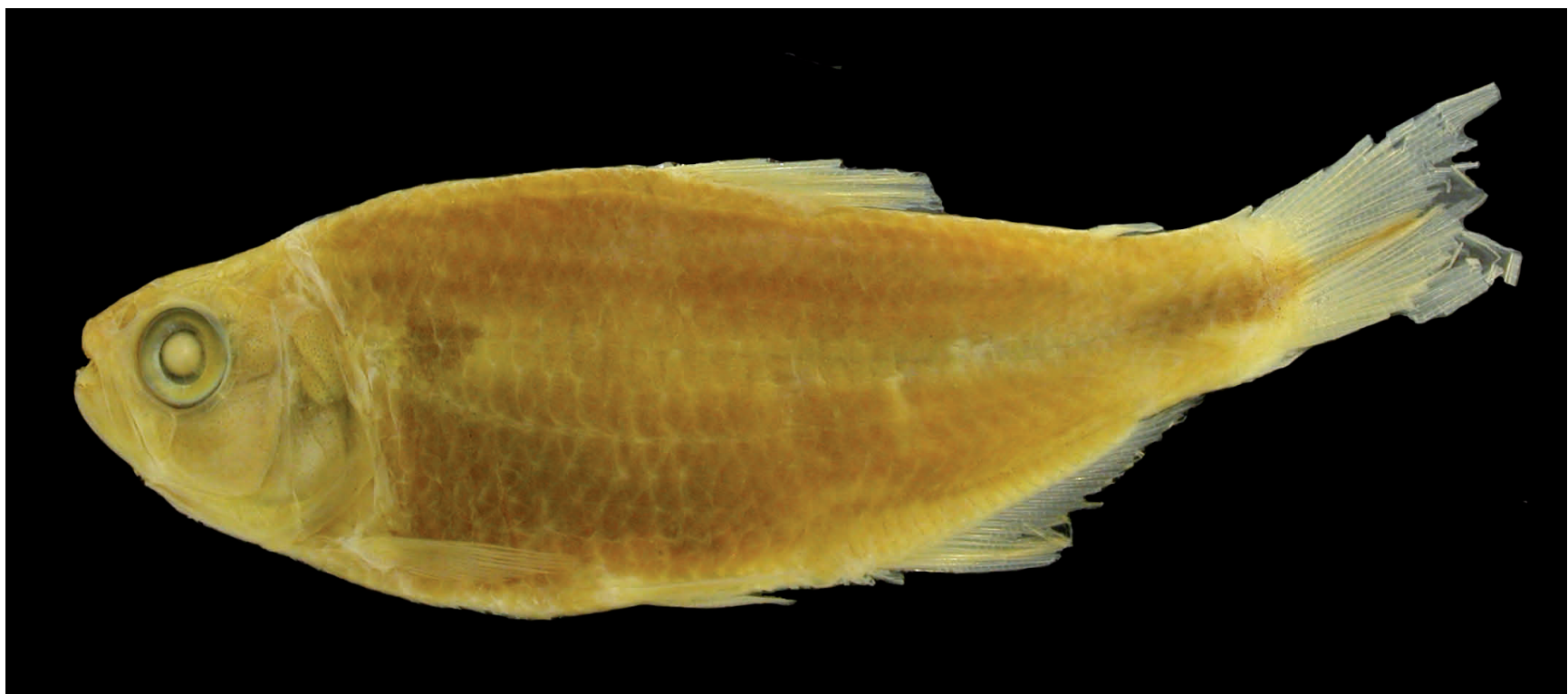

Fig. 6. Astyanax laticeps, ANSP 21852, holotype, $54.1 \mathrm{~mm}$ SL, Rio Grande do Sul, Brazil.

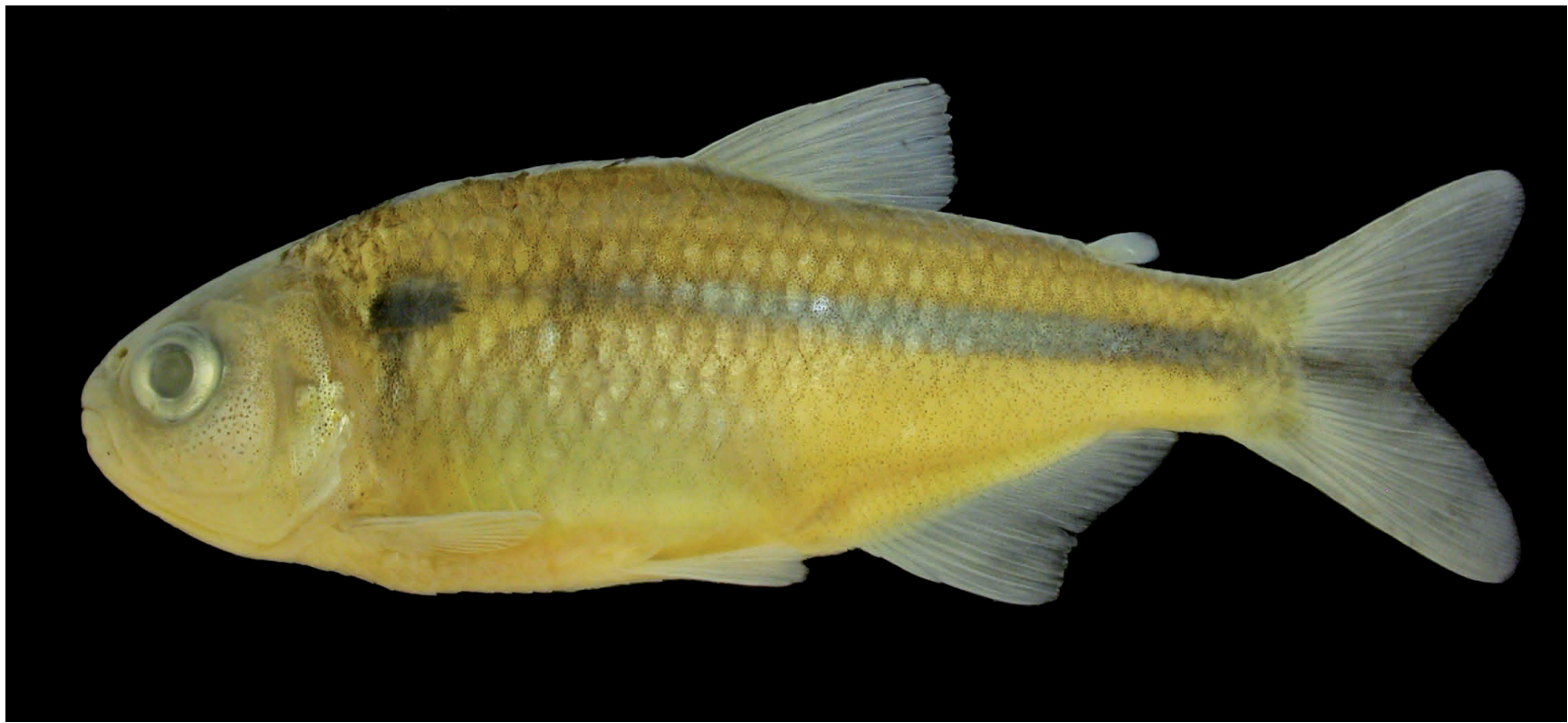

Fig. 7. Astyanax laticeps, MCP 35425, 61.2 mm SL, tributary of rio Ivaí, rio Jacuí drainage, Júlio de Castilhos, Rio Grande do Sul, Brazil.

extending from the humeral spot to caudal fin base; faint dark pigmentation present on middle caudal-fin rays. Midlateral body stripe expanded dorsally and ventrally to caudal fin base, forming small caudal spot. Humeral spot, conspicuous, horizontally elongate located over 3 to 5 vertical series of scales and extending over 2 horizontal series of scales above of the lateral line; with a narrow anteroventral downward extension past lateral line and extending over one, rarely two, vertical series of scales (Figs. 4b and 7). Humeral spot can vary in shape with upper portion almost rounded or slightly wider than lower portion in small specimens around $40.0 \mathrm{~mm}$ SL (MCP 40807, and MUCP 940) and occasionally in large specimens $(53.1 \mathrm{~mm} \mathrm{SL}$, MUCP 3250 , and $66.8 \mathrm{~mm} \mathrm{SL}, \mathrm{MCP} 34533$ ). Fins with dispersed dark chromatophores. Specimens a few days fixed in formalin (MCP 33312), all fins red-orange pigmented.

Sexual dimorphism. Males with thick, well-developed retrorse bony hooks on pelvic-fin and anal-fin rays. One paired bony hook per lepidotrichia in the last unbranched anal-fin ray and first to eighth anal-fin branched rays on middle and distal portions of rays. One paired bony hook per lepidotrichia on entire first to sixth pelvic-fin branched rays. Anal fin profile slightly concave to straight in males, concave in females. In males up to $60 \mathrm{~mm} \mathrm{SL}$, tip of pelvic fin reaches or slightly passes the anal fin origin, and tip of pectoral fin extends beyond the pelvic fin origin. In females, both fins do not reach the anal and pelvic fin origins, respectively. Gill glands 
(Burns \& Weitzman, 1996) were not found macroscopically on first gill arch in either males or females.

Distribution. Astyanax laticeps is known from the coastal drainages of Uruguay (arroyo Don Carlos) and Brazil to south of the Paraná State (rio Cubatão draining to baía de Guaratuba), and rio Uruguay drainage (Fig. 5). This finding substantially extends the distribution of the species reported by Azpelicueta \& Loureiro (2009).

Geographic variation. All meristic characters analyzed among A. laticeps populations showed wide overlap, except for three

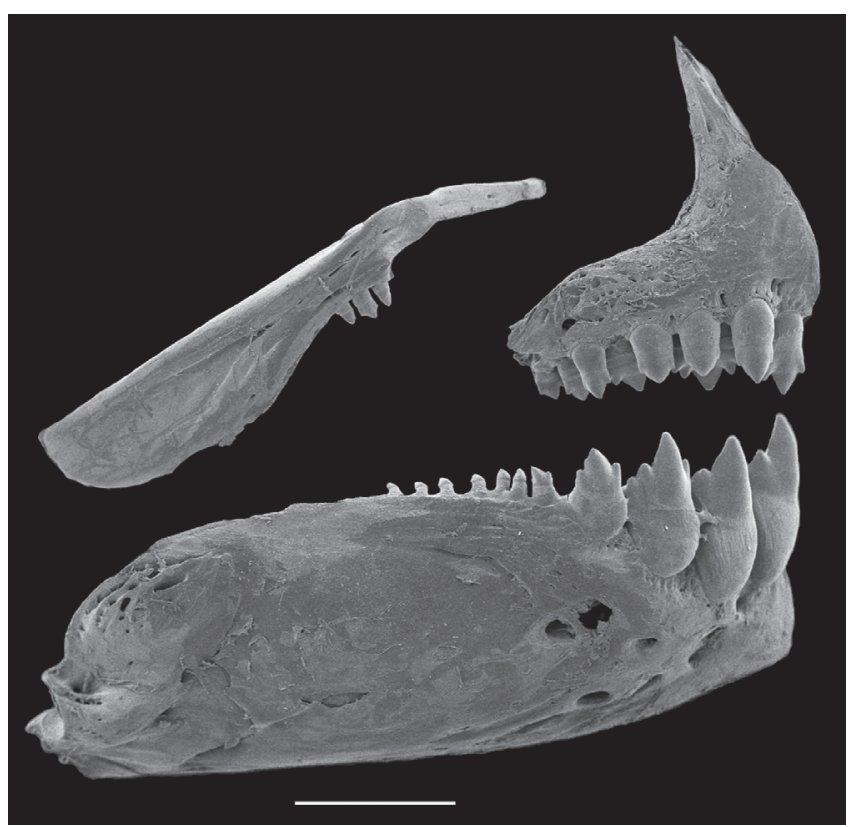

Fig. 8. Astyanax laticeps, UFRGS 4576, male, $49.2 \mathrm{~mm} \mathrm{SL}$. SEM image of upper and lower jaws, right side. Scale bar $=1 \mathrm{~mm}$. counts (lateral line and caudal peduncle scales, and branched anal-fin rays). Kruskal-Wallis nonparametric multiple comparisons indicate significant differences between population samples. Dunn's method shows differences in the number of lateral line scales between the rio Cubatão Norte and rio Itapocu populations and other populations, except that from the rio Tramandaí drainage (Fig. 9). The same count was not significantly different between the rio Cubatão and rio Itapocu populations. In the counts of scales around the caudal peduncle, the rio Cubatão Norte population was significantly different from all other populations, except the rio Itapocu (Fig. 10). The same pattern occurred in the number of branched anal-fin rays between the rio Cubatão Norte and other populations, except the rio Itapocu. This count was significantly different between the rio Itapocu and other populations, except the rio Mampituba (Fig. 11). Significant differences were found in the number of lateral line scales between the rio Mampituba and rio Tubarão populations and the others, except the rio Itajaí and laguna dos Patos system.

The morphometric data analyzed by percentages and PCA did not reveal at all the discriminate populations (Figs. 12-14, Table 3). The Mampituba population can be partially discriminated from those of the laguna dos Patos, Tramandaí, and Itapocu drainages. The variables that most influenced the discrimination on the third axis (explaining $0.89511 \%$ of the variance) were interorbital width and caudal peduncle length on the positive side and anal fin base length and snout length on the negative side (Fig. 12). When only females were analyzed, the populations of the Tramandaí and Mampituba drainages can be partially discriminated from each other. The most influenced measurement was the caudal peduncle length and interorbital width on the negative side on the second axis (explaining $0.7729 \%$ of the variance) and the anal fin base length and snout length on the positive side (Fig. 13). The PCA for males showed that the populations Tramandaí

Table 2. Morphometric data of populations of Astyanax laticeps. Laguna dos Patos system $(\mathrm{n}=68)$, rio Tramandaí drainage $(n=77)$, rio Mampituba drainage $(n=26)$, rio Tubarão drainage $(n=16)$, rio Itajaí drainage $(n=25)$, rio Itapocu drainage $(n=$ $15)$, and rio Cubatão Norte drainage $(n=44)$.

\begin{tabular}{|c|c|c|c|c|c|c|c|c|c|c|c|c|c|c|}
\hline & \multicolumn{2}{|c|}{ Laguna dos Patos } & \multicolumn{2}{|c|}{ Tramandaí } & \multicolumn{2}{|c|}{ Mampituba } & \multicolumn{2}{|c|}{ Tubarão } & \multicolumn{2}{|c|}{ Itajaí } & \multicolumn{2}{|c|}{ Itapocu } & \multicolumn{2}{|c|}{ Cubatão Norte } \\
\hline & Range & Mean & Range & Mean & Range & Mean & Range & Mean & Range & Mean & Range & Mean & Range & Mean \\
\hline Standard length (mm) & $45.6-1$ & 66.9 & $46.5-94.2$ & 70.9 & $36.4-81.4$ & 51.6 & $36.6-97.1$ & 59.2 & $44.2-105.9$ & 66.7 & $47.8-92.2$ & 69.2 & $46.6-97.3$ & 66.7 \\
\hline \multicolumn{15}{|c|}{ Percents of standard length } \\
\hline Predorsal distance & $49.9-58.0$ & 53.8 & $50.4-55.6$ & 53.3 & $.4-57.3$ & 52.3 & $51.2-56.4$ & 54.0 & $52.1-56.3$ & 53.8 & 54.2 & 51.6 & .0 & 52.4 \\
\hline Prepelvi & $43.9-5$ & 48.2 & $45.1-51.3$ & 47.9 & $46.1-51.2$ & 48.3 & $4.5-50.7$ & 48.2 & 50.8 & 49.1 & $5-50.9$ & 48.5 & 0.6 & 47.8 \\
\hline Prepec & 0.8 & 27.0 & $5.0-29.2$ & 26.9 & $5.8-29.3$ & 27.8 & $5.1-27.8$ & 26.6 & $24.5-31.1$ & 27.0 & $23.5-28.5$ & 26.3 & 23.6 & 26.9 \\
\hline Preana & & 66.7 & $.8-70.4$ & 6.5 & $2-69.7$ & 65.7 & & 66.8 & & 68.2 & 68.8 & 66.5 & & 66.0 \\
\hline $\mathrm{Cau}$ & 3.7 & 12.7 & 1.2-14.2 & 12.7 & $0.7-12.8$ & 11.6 & $0.7-13.3$ & 11.9 & $10.8-13.0$ & 12.0 & $10.3-12.2$ & 11.2 & 10.0 & 11.8 \\
\hline $\mathrm{Cau}$ & 6.1 & 14.3 & $12.7-16.3$ & 14.1 & $1-16.5$ & 15.1 & $.7-16.0$ & 14.1 & 6.7 & 15.1 & $12.2-16.0$ & 14.6 & 5.9 & 14.4 \\
\hline & 20.8 & 25.5 & $2.1-27.5$ & 24.9 & $1.3-27.5$ & 24.5 & $22.0-27.5$ & 24.7 & & 23.4 & $23.6-28.0$ & 25.7 & 22.7 & 26.3 \\
\hline Dor & 20.4 & 23.6 & $1.9-27.0$ & 24.6 & $3.4-28.0$ & 25.5 & $20.0-26.3$ & 23.1 & $21.0-28.2$ & 24.1 & $22.1-25.8$ & 24.2 & $21.9-2$ & 25.6 \\
\hline & $14.9-$ & 17.4 & $4.5-20.6$ & 17.3 & $8-18.8$ & 16.9 & 4.6-19.6 & 17.2 & $15.2-18.9$ & 16.9 & $16.3-19.8$ & 17.9 & 14.3 & 18.2 \\
\hline & & 21.1 & $7.8-24.3$ & 20.9 & $4-22.9$ & 21.1 & $.5-23.6$ & 21.1 & $4-23.9$ & 20.9 & $20.2-24.8$ & 22.6 & $20.1-$ & 22.9 \\
\hline Head length & 23.4 & 26.7 & $24.5-29.3$ & 27.0 & $25.2-30.8$ & 28.5 & $24.6-29.5$ & 27.3 & $24.6-31.7$ & 27.4 & $24.2-28.5$ & 26.4 & $25.1-29.6$ & 27.5 \\
\hline \multicolumn{15}{|c|}{ Percents of head length } \\
\hline & $8.8-48.4$ & 44.4 & $41.6-49.5$ & 46.1 & $39.5-46.6$ & 42.9 & $40.2-45.5$ & 43.3 & $40.5-47.5$ & 44.0 & $37.0-49.1$ & 45.4 & $39.6-47.1$ & 44.6 \\
\hline & & 31.7 & $27.4-38.4$ & 31.7 & $28.4-38.7$ & 33.1 & $27.5-35.6$ & 31.5 & $25.1-36.0$ & 30.6 & $25.0-36.8$ & 32.0 & $28.2-36.9$ & 32.8 \\
\hline Interorbital width & $28.6-40.2$ & 34.2 & $30.0-38.1$ & 34.4 & $29.7-38.0$ & 33.0 & $27.4-40.1$ & 32.3 & $30.7-38.7$ & 35.0 & $26.8-37.5$ & 34.3 & $30.3-36.7$ & 34.6 \\
\hline
\end{tabular}


and Mampituba, and Itajaí and Cubatão Norte drainages are discriminated from each other on the second axis (explaining $2.4185 \%$ of the variance) (Fig. 14). Pectoral and pelvic fin lengths were the variables that were influenced most on the negative side, and snout length and body depth on the positive side.

Despite the above-mentioned differences, there is overlapping of ranges of meristic and percentage data. In the meristic data analyzed, the Itapocu and Cubatão Norte populations showed higher median values compared to the other populations, suggesting that these populations may be distinct. However, there is overlapping of the extreme values of these characters when compared with southern populations. Besides, no diagnostic characters were found to discriminate the Itapocu and Cubatão Norte populations from the others. The few differences in PCA did not show any rational geographic pattern in the entire distribution area of the species. Therefore, we considered all populations analyzed as Astyanax laticeps.

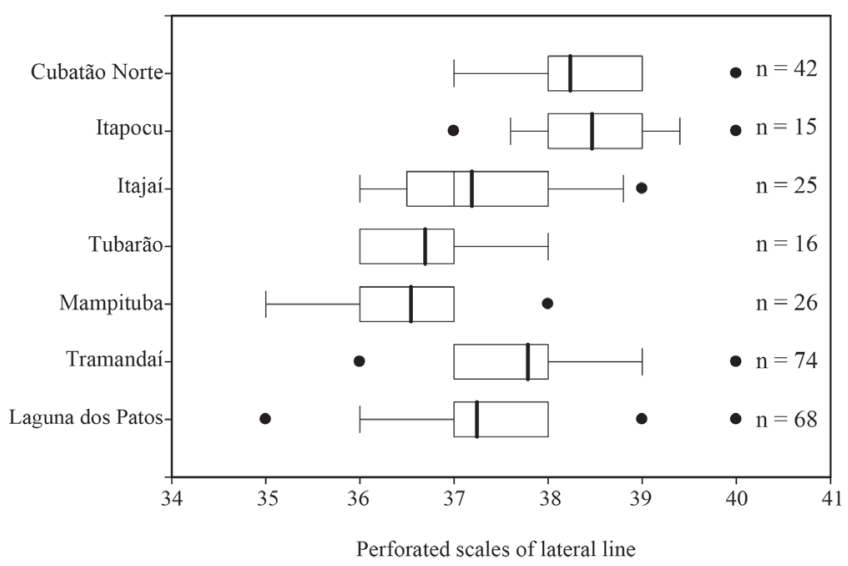

Fig. 9. Tukey box plots of number of perforated scales of lateral line in Astyanax laticeps populations by river drainage from south to north. Mean represented by thick vertical bar and $25^{\text {th }}$ and $75^{\text {th }}$ percetiles as lateral borders of box plots.

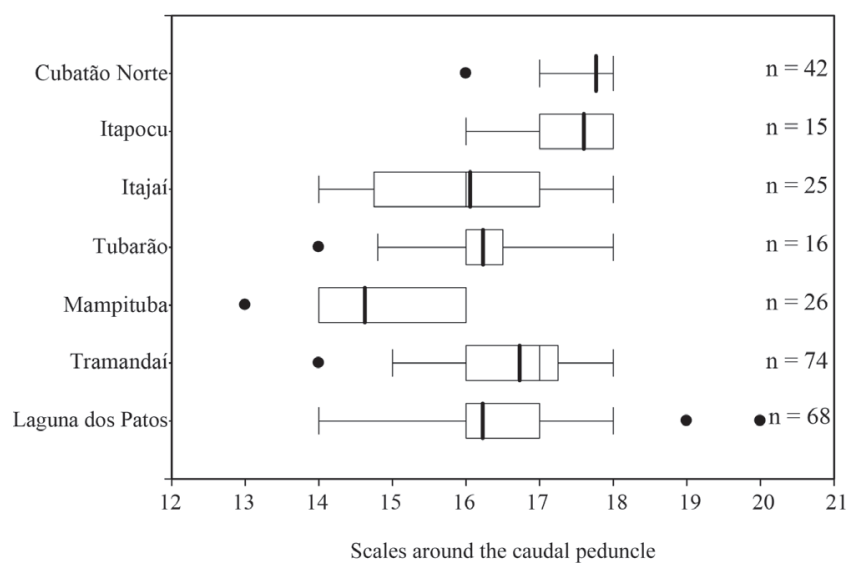

Fig. 10. Tukey box plots of number of scales around the caudal peduncle in Astyanax laticeps populations by river drainage from south to north. Mean represented by thick vertical bar and $25^{\text {th }}$ and $75^{\text {th }}$ percetiles as lateral borders of box plots.

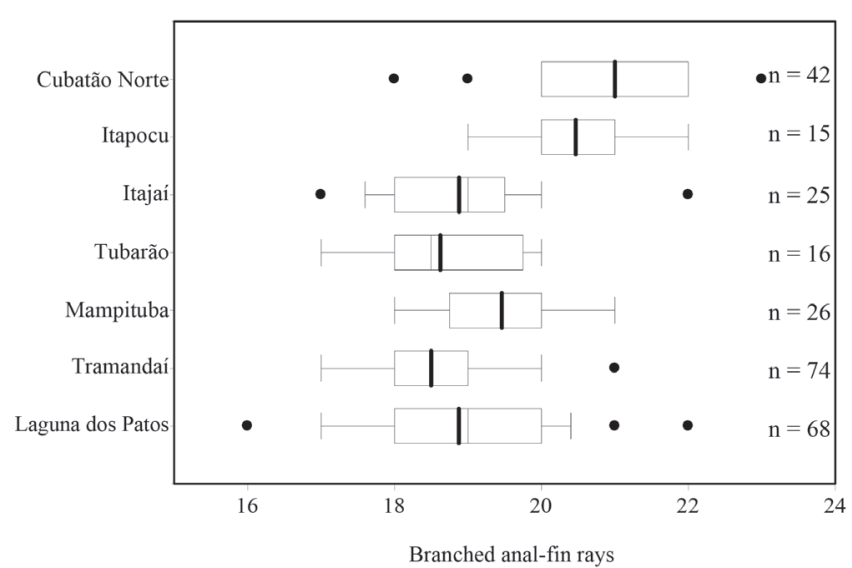

Fig. 11. Tukey box plots of number of branched anal-fin rays in Astyanax laticeps populations by river drainages from south to north. Mean represented by thick vertical bar, and $25^{\text {th }}$ and $75^{\text {th }}$ percetiles as lateral borders of box plots.

Among the discerning taxonomic studies, including species widely distributed in the coastal rivers of south and southeast Brazil, only Mimagoniates microlepis (Steindachner) showed a distribution similar to that of $A$. laticeps (Weitzman et al., 1988; Menezes \& Weitzman, 1990, 2009). Weitzman et al. (1988) found divergent live color patterns between some isolated populations of M. microlepis, and related this divergence to the possible initial process of speciation. In the present study, the tendency toward higher median values for the populations from Itapocu and Cubatão drainages could be indicative of the same early process.

Material examined. Holotype. ANSP 21852 (54.1 mm SL), Rio Grande do Sul, Brazil, 1882, H. H. Smith. Paratypes. ANSP 21743, 4 (4, 38.0-50.8 mm SL), same data of holotype. Non-types: Brazil: Rio Grande do Sul: laguna dos Patos system: rio Jacuí drainage: UFRGS 6649, 3 (53.1-61.3 mm SL), UFRGS 6651, 2 (56.6-61.8 mm SL), swamp on the area designed to Condomínio Alphaville, lago Guaíba basin, Porto Alegre. MCP 8246, 4 (2, 51.1-68.2 mm SL), MCP 10140, 3 (2, 68.4-72.9 mm SL), açude dos Peruffo, Vila Nova, Bento Gonçalves. MCP 8959, 25 (2, 52.4-56.5 mm SL), Linha Nova, Pirajá, Nova Petrópolis. MCP 15035, 5 (2, 87.8-92.5 mm SL), arroio Caguas. MCP 16564, 26 (5, 47.3-63.7 mm SL), stream and small dam on the Chácara do Seminário de Fazenda Souza, Caxias do Sul. MCP 17321, 5 (4, 53.5-77.2 mm SL), arroio Taquara, Lizete Farm, Boa Vista road about $5 \mathrm{~km}$ of BR 290, Minas do Leão. MCP 17345, 4 (2, 52.6-52.9 mm SL), arroio Martins, road BR 290, between Butiá and Minas do Leão, Butiá. MCP 18246, 3 (2, 51.1-68.2 mm SL), arroio at São José locality, Restinga Seca. MCP 19833, 8 (2, 95.3-106.8 mm SL), small dam near the road Minas do Leão to Dom Feliciano, Triunfo. MCP 19980, 3 (3, 97.1-104.0 mm SL), MCP 19983, 2 (2, 95.3-106.8 mm SL), MCP 20019, 1, 96.7 mm SL, arroio Feitoria, Sapiranga. MCP 20052, 3 (2, 92.0-95.6 mm SL), arroio Feitoria, Ivoti. MCP 21269, 1 (1, $45.5 \mathrm{~mm} \mathrm{SL})$, arroio Passo das Éguas, on road between Tunas and Jacuizinho, Tunas. MCP 22759, 1, $80.0 \mathrm{~mm} \mathrm{SL}$, arroio Tipiáia, about $13 \mathrm{~km} \mathrm{~N}$ of Júlio de Castilhos, on road to Cruz Alta, Júlio de Castilhos. MCP 23007, 1 (1, $63.5 \mathrm{~mm} \mathrm{SL})$, arroio Bom Jardim, III Pólo Petroquímico, Triunfo. MCP 26127, 8 (8, 68.1-84.2 $\mathrm{mm}$ SL), arroio Cadeia, Santa Maria do Herval. MCP 26539, 3 (2, 


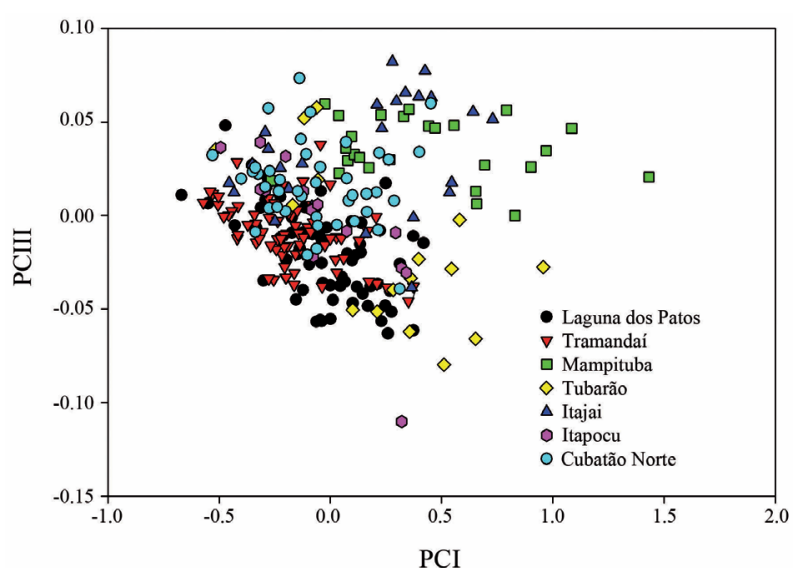

Fig. 12. Projection of individual scores in the space of first and third Principal Component axis for the populations of males and females of Astyanax laticeps.

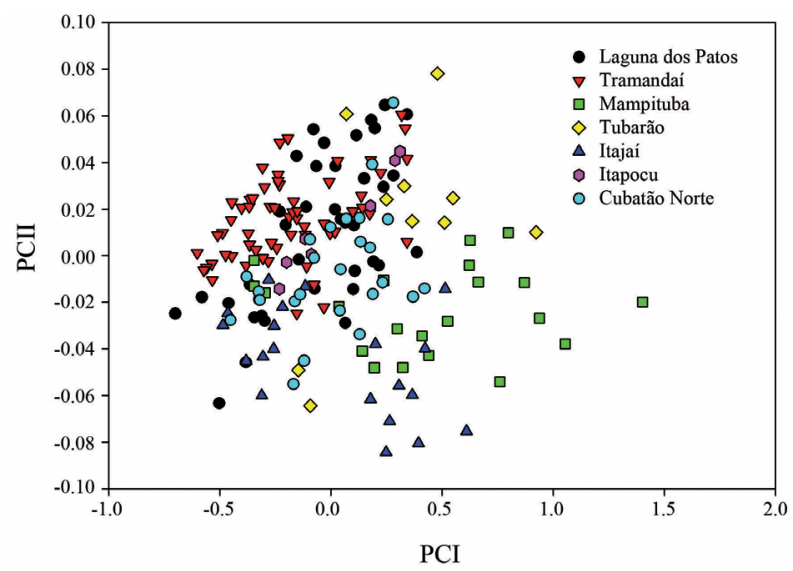

Fig. 13. Projection of individual scores in the space of first and second Principal Component axis for the populations of females of Astyanax laticeps.

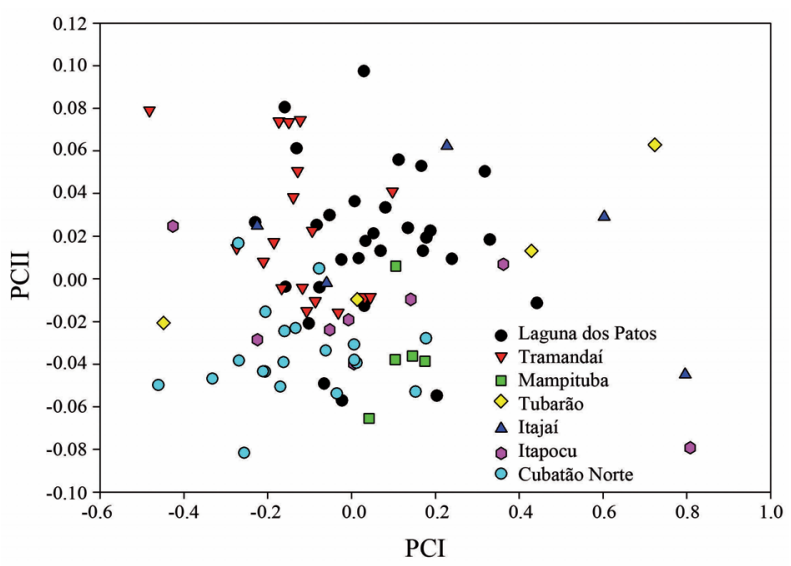

Fig. 14. Projection of individual scores in the space of first and second Principal Component axis for the populations of males of Astyanax laticeps.

62.0-83.0 mm SL), tributary of rio Jacuí at Nova Boêmia, Agudo. MCP 27772, 2, 60.7-69.6 mm SL, lajeado do Gringo at Linha das Pedras, Ibarama. MCP 28118, 1, 69.3 mm SL, arroio Amoras, Viamão. MCP 28954, 2, 53.0-60.7 mm SL, arroio Tolloti, tributary of arroio dos Ratos, Mariana Pimentel. MCP 30890, 4, 47.4-77.1 mm SL, arroio Caçador, Canela. MCP 32452, 1, $59.2 \mathrm{~mm} \mathrm{SL}$, tributary of rio Morungava, rio Gravataí basin, Morungava. MCP 33312, 11, 28.6$53.0 \mathrm{~mm} \mathrm{SL}$, tributary of the rio Ivaí in the PCH Eng. Ernesto Jorge Dreher, Júlio de Castilhos. MCP 35425, 5, 58.6-61.5 mm SL, tributary of rio Ivaí, Júlio de Castilhos. MCP 33678, 1, $56.5 \mathrm{~mm}$ SL, passo do inferno, tributary of rio Taquari, Antônio Prado. MCP 34533, 3, 45.4-65.9 mm SL, tributary of arroio Grande, Mariana Pimentel. MCP 34803, 4, 34.5-65.0 mm SL, arroio dos Ratos, São Jerônimo. MCP 34553, 3, 43.3-67.0 mm SL, tributary of arroio Grande, Mariana Pimentel. MCP 34802, 17, 26.8-73.4 mm SL, headwaters of arroio Quitéria, tributary of arroio dos Ratos, São Jerônimo. MCP 40513, 2, 29.9-36.3 mm SL, rio Cadeia, bridge at $3 \mathrm{~km}$ from Jacaré beach, Santa Maria do Herval. MCP 42762, 3, 48.6-68.5 mm SL, arroio Pedacino, Caxias do Sul. UFRGS 6815, 7, 21.2-41.1 mm SL, arroio Lava Pés, São Francisco de Paula. UFRGS 8191, 50, 27.3-74.1 mm SL, tributary of rio Capivari, Bota Farm, Encruzilhada do Sul. UFRGS 8789, 20, 36.3-77.2 mm SL, tributary of arroio Iruí at Limoeiro Farm, Rio Pardo. Rio Camaquã drainage: MCP 25753, 8 (3, 55.7-71.8 mm SL), arroio Maria Ulghim, Camaquã. MCP 25763, 1, 38.3 mm SL, tributary of arroio das Neves, Santana da Boa Vista. MCP 39210 , 7, 21.1-64.6 mm SL, MCP 39213, 37, 18.4-64.8 mm SL, MCP 39216, 4, 21.9-47.5 mm SL, arroio on the road to Chafri farm, Boqueirão, Encruzilhada do Sul. MCP 40807, 23, 18.0-53.4 mm SL, tributary of arroio das Lavras on the road between Lavras do Sul and Bagé, Lavras do Sul. MUCP 940, 26 (3, 55.1-61.5 mm SL), arroio do Padre, Arroio do Padre. São Gonçalo drainage: MCP 20548, 7 (1, 63.6 mm SL), MCP 25129, 7, 30.2-44.6 mm SL, stream on the road between Pedro Osório and Basílio, Pedro Osório. MCP 20841, 1, 25.7 mm SL, arroio Reduzinho between Pedro Osório and Basílio, Pedro Osório. MCP 25117, 8 (2, 54.5-56.4 mm SL), arroio Paraguaia about $3 \mathrm{~km}$ of Pinheiro Machado, Pinheiro Machado. MCP 34763, 1, 56.0 mm SL, tributary of arroio Paraguaia, Pinheiro Machado. MCP 34734, 1, $38.8 \mathrm{~mm}$ SL, arroio Mata Olho on the road between Pedro OsórioBasílio, Pedro Osório. MCP 34736, 1, $62.0 \mathrm{~mm}$ SL, headwaters of arroio Alegria, Pedras Altas. MCP 34739, 7, 28.4-41.2 mm SL, creek on the road Pedro Osório-Basílio, Pedro Osório. MCP 34761, 2, 46.2-46.3 mm SL, stream between Herval and Pedras Altas, Pedras Altas. MCP 34790, 1, 36.9 mm SL, arroio Arambaré between Pedro Osório and Herval, Herval. MUCP 639, 1 (1, 93.9 mm SL), headwaters of sanga da Gama, Monte Bonito, Pelotas. MUCP 1098, 1 (1, 78.9 mm SL), arroio Schwartz, Turuçu. MUCP 3222, 18, 29.8-48.2 mm SL, headwaters of the sanga do Sonho, Monte Bonito, Pelotas. MUCP 3228, 1 (1, $50.5 \mathrm{~mm} \mathrm{SL})$, headwaters of arroio Candiotinha, Torrinhas, Pinheiro Machado. MUCP 3250, 27 (10, 50.3-68.9 mm SL), headwaters of sanga do Vale, Cerro das Almas, Capão do Leão. MUCP 3330, 14, 37.6-49.5 mm SL, headwaters of rio Pelotas-Mirim, Canguçu. Rio Jaguarão drainage: MCP 27271, 5, 38.1-64.5 mm SL, arroio Quebra Jugo no passo dos Pinheiros, Candiota. UFRGS 3909, 1, 56.1 mm SL, UFRGS 4577, 4, 45.4-76.7 mm SL, arroio Quebra Jugo, Candiota. UFRGS 4719, 10, 28.8-51.9 mm SL, UFRGS 4575, 31, 15.5-63.4 mm SL, UFRGS 4576, 10 c\&s, 38.7-65.1 mm SL, arroio Poacá, Candiota. Other drainages in laguna dos Patos system: MCP 23842, 4 (1, 62.2 mm SL), tributary of arroio Viúva Teresa, São Lourenço do Sul. MCP 23843, 2 (2, 54.9-62.9 mm SL), tributary of arroio São Lourenço, São Lourenço do Sul. MCP 23844, 2, 26.3-32.4 $\mathrm{mm}$ SL, arroio Capivaras between Sentinela do Sul and Vila Aurora, Sentinela do Sul. Rio Uruguay drainage: Rio Grande do Sul: MCP 37200, 10, 33.1-44.3 mm SL, arroio Cinamomo, tributary of rio Ijuí, Roque Gonçalez. UFRGS 7036, 1, $36.8 \mathrm{~mm} \mathrm{SL}$, stream on the road to Pirapó, São Nicolau. Rio Tramandaí drainage: rio Maquiné drainage: Maquiné municipality: MCP 13600, 7 (1, 
Table 3. Individual scores of the first and third Principal Component axis for Astyanax laticeps. A = specimens; 1-68, from laguna dos Patos; 69-142, Tramandaí; 143-168, Mampituba; 169-184, Tubarão; 185-209, Itajaí-Açu; 210-224, Itapocu; 225-266, Cubatão Norte.

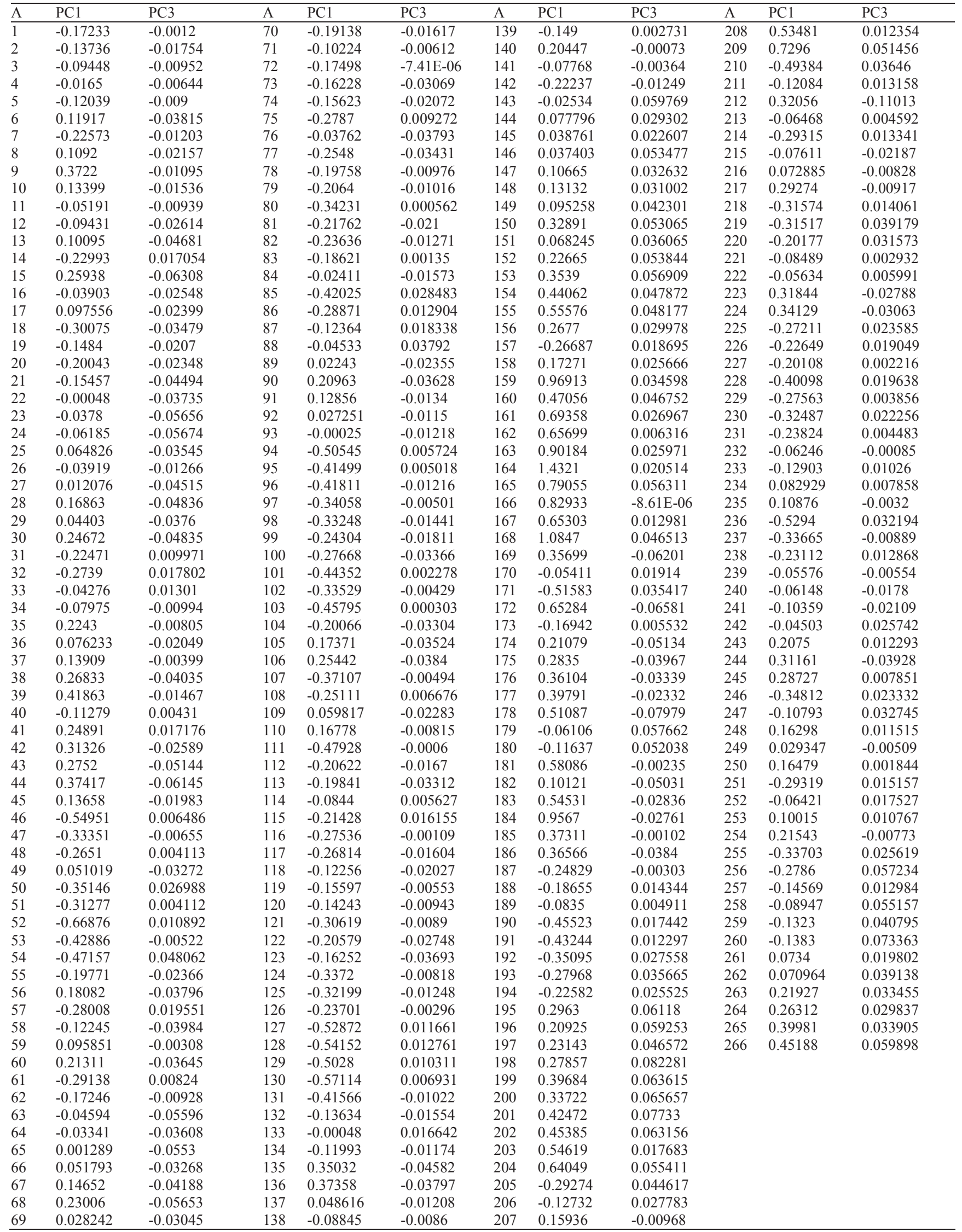


$65.9 \mathrm{~mm}$ SL), MCP 14858, 4 (2, 72.2-84.4 mm SL), MCP 20987, 8 (8, 66.8-82.0 mm SL), MCP 25690, 3 (3, 73.5-79.4 mm SL, 1 c\&s, $58.0 \mathrm{~mm} \mathrm{SL})$, MCP 25704, 11 (6, 51.4-64.8 mm SL), arroio Água Parada, tributary of rio Maquiné. MCP 14306, 2 (2, 65.7-67.1 mm $\mathrm{SL})$, headwaters of rio Maquiné, about $2 \mathrm{~km}$ above Luca Mundo Novo dam. MCP 14790, 10 (3, 46.5-65.1 mm SL), MCP 25396, 1 (1, 64.8 mm SL), arroio Pinheiro. MCP 20705, 6 (3, 49.1-63.9 mm SL), tributary of rio Maquiné. MCP 20829, 1, $45.2 \mathrm{~mm} \mathrm{SL}$, rio Maquiné. MCP 25343, 5 (5, 69.5-78.7 mm SL), MCP 25406, 6 (5, 62.3-88.5 mm SL), MCP 25411, 1, 100.5 mm SL, MCP 25420, 3 (3, 68.6-81.2 mm SL), MCP 25446, 2 (1, $69.1 \mathrm{~mm} \mathrm{SL})$, arroio Ligeiro, Barra do Ouro. MCP 25368, 3 (3, 57.3-61.9 mm SL), MCP 25407, 12 (7, 54.2-94.1 mm SL), Maquiné. MCP 25705, 14 (8, 72.6-87.3 mm SL), arroio Encantado. MCP 25413, 4 (4, 68.8-77.2 $\mathrm{mm} \mathrm{SL})$, tributary of rio Forqueta. MCP 25421, 1 (1, 66.1 mm SL), rio Forqueta. MCP 25714, 4 (4, 80.6-92.3 mm SL), tributary of left margin of rio Maquiné. UFRGS 4525, 4 (2, 73.7-90.8 mm SL), rio Maquiné, Barra do Ouro. Rio Três Forquilhas drainage: MCP 10791, 6 (6, 46.5-68.6 mm SL), MCP 20830, 1, $45.2 \mathrm{~mm} \mathrm{SL}$, tributary of rio Três Forquilhas, Itati. MCP 14687, 2, 38.2-39.7 $\mathrm{mm}$ SL, rio Mitmann at Vila Nova, about $10 \mathrm{~km}$ of road BR 101 to Itati. MCP 14746, 4, 37.2-49.7 mm SL, rio do Padre at Itati. MCP 21091, 1 (1, 68.1mm SL), headwaters rio Três Forquilhas, Três Forquilhas. MCP 25275, 1, $38.0 \mathrm{~mm}$ SL, rio Três Pinheiros on road to Vila Itati, about $7 \mathrm{~km} \mathrm{~N}$ of road BR 101, Terra de Areia. UFRGS 4413, 1 (1, 65.7 mm SL), rio Três Forquilhas. UFRGS 6317, 1, 68.4 mm SL, UFRGS 6646, 2, 78.4-91.0 mm SL, stream at Reserva Biológica da Mata Paludosa, Terra de Areia. Rio Mampituba drainage: MCP 23719, 1, $33.0 \mathrm{~mm} \mathrm{SL}$, rio Negro on the road between Morrinhos do Sul and Praia Grande, Morrinhos do Sul. Santa Catarina: rio Mampituba drainage: Praia Grande: MCP 11502, 9 (9, 27.3-66.5 mm SL), rio Faxinalzinho, Mãe dos Homens. MCP 14741, 2 (2, 38.7-40.6 mm SL), arroio Facão, Mãe dos Homens. MCP 14750, 3 (3, 59.3-81.3 mm SL), tributary of rio Canoas, about $2 \mathrm{~km}$ of Praia Grande. MCP 23552, 2 (2, 36.2$40.1 \mathrm{~mm} \mathrm{SL})$, tributary of rio Sertão, Cachoeira, about $9 \mathrm{~km} \mathrm{NE}$ of Praia Grande. MCP 23614, 10 (10, 44.7-60.9 mm SL, 2 c\&s, 58.1$60.1 \mathrm{~mm} \mathrm{SL}$ ) arroio Maia Coco at Vila Rosa about $5 \mathrm{~km} \mathrm{NW}$ of Praia Grande. Rio Araranguá drainage: UFRGS 6204, 13, 40.9-86.4 mm SL, rio Mãe Luzia, Treviso. Rio Tubarão drainage: MCP 10999, 3 (3, 29.4-30.3 mm SL), mouth of rio Sanga da Areia, Tubarão. MCP 11013, 5, 24.2-28.9 mm SL, rio Capivari, near at Gravatal. MCP 11023, 9 (8, 28.3-41.4 mm SL), tributary of rio Tubarão. MCP 11023, 8 (8, 27.3-41.4 mm SL), tributary of rio Tubarão, Tubarão. MCP 11025, 1, $40.1 \mathrm{~mm} \mathrm{SL}$, rio Tubarão, near at Rio do Pouso. MCP 11028, 40 (17, 27.3-77.2 mm SL), rio Sanga da Areia, Tubarão. MCP 17481, 3 (3, 36.5-49.2 mm SL), tributary of rio Pinheiros on road SC 407, Anitápolis. MCP 17614, 7 (5, 44.1-74.6 mm SL, 2 c\&s, 52.4-54.2 mm SL), tributary of rio Pinheiros, Anitápolis. MCP 25585, 2 (2, 66.4-97.1 mm SL), rio Capivari, São Martinho. UFRGS 6203, 76, 34.9-60.4 mm SL, rio Lageado on area of the USITESC, Urussanga. Rio Itajaí-Açu drainage: MCP 11504 , 12 (12, 44.1-63.3 mm SL), tributary of rio Itajaí, on road Blumenau to Rio do Sul, Ibirama. MCP 16487, 2 (2, 45.6-47.8 mm SL), Ribeirão São Luis, tributary of rio Benedito Novo, Apiúna. MCP 16567, 1 $59.8 \mathrm{~mm}$ SL small stream on road between Taió and Passo Manso, Taió. MCP 21785, 3 (3, 75.1-83.2 mm SL), rio Palmeira, Rio dos Cedros. MCP 21787, 7 (7, 69.6-105.8 mm SL), rio dos Cedros, Rio dos Cedros. Rio Itapocu drainage: MCP 14508, 30 (19, 49.7-92.2 mm SL), tributary of rio Itapocu, Corupá. Rio Cubatão Norte drainage (baía de São Francisco): MCP 10707, 7 (7, 46.5-72.4 $\mathrm{mm}$ SL), rio Prata, Joinville. MCP 11275, 17 (10, 52.8-97.3 mm
SL), arroio Lindo, Pirabeiraba, Joinville. MCP 11278, 18 (13, 55.8$86.4 \mathrm{~mm} \mathrm{SL})$, rio Seco, $\mathrm{km} 10$ on road SC 280, Joinville. MCP 14048, 13 (12, 46.7-84.2 mm SL, rio Garuvá on road BR 101, about 2 km from Santa Catarina and Paraná boundary, Garuvá. Paraná: rio Cubatão drainage (baía de Guaratuba): MCP 13665, 1 (1, 65.4 mm SL), rio São João, Pedra Branca do Araraquara at BR 376 between Curitiba and Joinville, Pedra Branca. MCP 20375, 1 (1, $85.9 \mathrm{~mm}$ SL), tributary of rio Cubatão, Guaratuba. MCP 41260, 3, 35.1-39.4 mm SL, rio Araraquara, BR 1013 km N from Garuvá. Uruguay: UFRGS 2962, 3, 56.0-65.2 mm SL, arroyo Don Carlos, laguna Castilhos drainage, coastal river drainage, Rocha, Departamento Rocha.

\section{Discussion}

Astyanax obscurus and A. laticeps have the characters and general body morphology of the species of the $A$. scabripinnis species complex which was discussed by Moreira-Filho \& Bertollo (1991) and Bertaco \& Malabarba (2001) and later tentatively delimited by Bertaco \& Lucena (2006).

The species name A. scabripinnis has been largely used to refer to populations of Astyanax from the rio Paraná basin and coastal river drainages of south and southeast Brazil that possess similar features described for the A. scabripinnis species complex (e.g., Castro \& Vari, 2004; Villela et al., 2002). According to our results, most of the citations of $A$. scabripinnis for the rio Uruguay drainage (Rio Grande do Sul State) and costal river drainages of the States of Santa Catarina and Paraná (rio Cubatão), must be referred to as $A$. laticeps. Recently, Miquelarena \& Menni (2005) recognized $A$. scabripinnis in their key for Astyanax species from Argentina. According to these authors, A. scabripinnis occurs in the Paraná and Uruguay River drainages in Argentina. The features of the humeral spot mentioned in the key indicate that the specimens examined by these authors are not $A$. laticeps or $A$. scabripinnis. According to Melo (2001) and Bertaco \& Lucena (2006), the occurrence of A. scabripinnis is restricted to Rio de Janeiro State, and the species may be extinct. A review of populations of Astyanax from the rio Paraná basin is necessary to explain the citation of $A$. scabripinnis for this basin.

Astyanax obscurus remained for one hundred and thirty years as a junior synonym of other Astyanax species and was considered only recently as a valid species (Lima et al., 2003; Bertaco \& Lucena, 2006; Melo \& Buckup, 2006) but without a taxonomic analysis. According to our results, the conclusion of these authors is confirmed here.

Bertaco \& Lucena (2006) included fifteen species in the $A$. scabripinnis species complex, distributed throughout south and southeast Brazil (drainages of the rios São Francisco, Itapemirim, Paraíba do Sul, Paraná, Uruguay and Tramandaí, and laguna dos Patos). Although A. obscurus is sympatric with A. laticeps, some differences between their habitats can be observed. Astyanax obscurus inhabits mainly headwater environments of the laguna dos Patos system. On the other hand, A. laticeps seems to exploit a larger diversity of niches and may also occur in the middle and lower courses of rivers, consequently showing a wider distribution, from coastal rivers in Uruguay to southern Paraná 
State in Brazil, and in the rio Uruguay drainage.

Haluch \& Abilhoa (2005) mentioned two other populations with a humeral spot similar to that of A. laticeps, Astyanax sp. $\mathrm{D}$ from rio Iguaçu basin and $A$. aff. scabripinnis from rio Morato, coastal drainage of Paraná State. Astyanax laticeps differs from Astyanax sp. D by the absence of bony hooks on the pectoral fin of males, and from $A$. aff. scabripinnis by the number of gill rakers in the lower branch of the first arch (10 vs. 11-16).

Therefore, with the increased number of Astyanax species that occur in the laguna dos Patos system, along with the difficulty that biologists have in the identification of these species, we find it opportune to present an identification key for these species. Some species included in the key may also occur in the drainages adjacent to laguna dos Patos system, namely $A$. brachypterygium (upper rio Uruguay), $A$. cremnobates (rio Tramandaí system), A. eigenmanniorum, $A$. sp. aff. fasciatus (sensu Melo \& Buckup, 2006), and $A$. jacuhiensis. The last three species are the object of taxonomic studies by the authors to determine their identity and true distribution.

Key for the species of Astyanax from laguna dos Patos system 1. Anterior humeral spot distinctively oval-shape ................. 2

1 '. Anterior humeral spot vertically elongate or other form but never oval-shape

2. Humeral spot trespassed by a diffuse vertical bar followed posteriorly by a second bar of same intensity, and without a narrow anteroventral downward extension surpassing the lateral line; body short and high (body depth 35.0$50.0 \% \mathrm{SL}$ ); branched anal-fin rays 22-28; absence of maxillary teeth; all fins green-yellow pigmented in life Astyanax jacuhiensis

2'. Humeral spot not trespassed by vertical bar and posterior bar absent, with a narrow anteroventral downward extension surpassing the lateral line; body elongate (body depth $30.7-39.0 \%$ of SL); branched anal-fin rays 15-23; maxilla with 1-3 teeth; all fins red-orange pigmented in life Astyanax laticeps

3. Presence of two humeral spots, the second diffuse .......... 4

3'. Presence of only one humeral spot .................................... 7

4. Head moderately sharp; branched anal-fin rays 22-27; larger orbital diameter (42.4-50.7\% of HL); $2-5$ (usually $3-4$ ) maxillary teeth; dentary teeth slender and spaced

Astyanax henseli

4'. Head robust; branched anal-fin rays 12-21 (rarely 22 or 23 ); smaller orbital diameter (24.8-37.7\% of HL); up to 3 (usually 1-2) maxillary teeth; dentary teeth thick ............... 5

5. First humeral spot with the dorsal portion wider and ventral portion narrow, not forming a wedge, and extending over 4 to 5 horizontal series of scales

Astyanax obscurus

5 '. First humeral spot with the dorsal portion slightly wider than ventral portion, forming a uniform wedge, and extending over 5 to 6 horizontal series of scales ............... 6

6. Branched anal-fin rays 13-15 (rarely 12 or 16, usually 13-14); small orbital diameter (24.8-34.8\% of HL); large caudal peduncle depth (12.2-15.3\% of SL) Astyanax brachypterygium
6'. Branched anal-fin rays 15-17 (rarely 14 or 18 , usually 16-17); large orbital diameter (28.1-37.7\% of HL); small caudal peduncle depth (10.4-14.2\% of SL) ... Astyanax cremnobates 7. Humeral spot extending over the series of scales above and below the lateral line, forming a uniform wedge, and extending over 5 to 6 horizontal series of scales; lateral line scales 34-36; branched anal-fin rays 21-24 Astyanax eigenmanniorum

7'. Humeral spot located only above of the lateral line scales, not forming a wedge, and extending over 2 to 3 horizontal series of scales; lateral line scales 38-41; branched anal-fin rays $25-30$

Astyanax sp. aff. fasciatus (sensu Melo \& Buckup, 2006)

Comparative material. In addition to the comparative material listed in Bertaco \& Lucena (2006), the following specimens were analyzed: Argentina, Misiones: Astyanax leonidas: MLP 9580, holotype, headwaters of arroyo Urugua-í, rio Paraná basin. Astyanax ojiara: MLP 9470, holotype, MLP 9471, 2 paratypes, arroyo Benítez, rio Uruguay drainage. Astyanax troya: MACN 8310, holotype, MCP 28438, 5 paratypes, UFRGS 10079, 5, arroyo Cuñapirú Chico, rio Paraná basin. Brazil: Astyanax eigenmanniorum: ANSP 21598, holotype, ANSP 21627, paratype, ANSP 21628, paratype, ANSP 21599, paratype, ANSP 21601, 2 paratypes, Rio Grande do Sul. MCP 25122, 4, canal São Gonçalo, Piratini, Rio Grande do Sul. Astyanax sp. aff. fasciatus: MCP 21378, 48, laguna dos Patos, São José do Norte, Rio Grande do Sul. Astyanax jacuhiensis: ANSP 21912, holotype, ANSP 2168321701, 19, ANSP 21606-21611, 6, ANSP 21913-21916, 4 paratypes, Jacuhy, Rio Grande do Sul. MCP 34801, 6, rio Pardinho, Santa Cruz do Sul, Rio Grande do Sul. Astyanax totae: MCP 37562, 8 paratypes, tributary of rio Tortuoso, affluent of rio Iguaçu, Balsa Nova, Paraná.

\section{Acknowledgements}

We are grateful for the loan of the type specimens to following curators: John Lundberg (ANSP), and Peter Barstch (ZMB). For information on some type specimens, we are grateful to Marilyn Weitzman (USNM). We owe especial thanks to Morevy Cheffe (MUCP) for selection and loan of specimens. CASL thanks to the Fundação de Amparo à Pesquisa do Rio Grande do Sul (FAPERGS) for the PIBIC fellowships (2000/2001) to Pierre Silveira, and is supported by fellowship from CNPq. We thank to CEMM (PUCRS) and CME (UFRGS) for the SEM preparations, and to Alexandre Scharcansky for preparing Figure 4 . This paper benefited from comments and criticisms by Luiz Malabarba and Fernando Carvalho (UFRGS). The senior author is financed by a postdoctoral fellowship from CNPq (Proc. 150042/2009-4), and is grateful for the fellowship from the California Academy of Sciences. This project is supported by CNPq (Proc. 479412/ 2008-1) and FAPERGS (Proc. 0903014). 


\section{Literature Cited}

Azpelicueta, M. M. \& M. Loureiro. 2009. Astyanax laticeps (Teleostei: Characiformes: Characidae) from rivers and streams of Uruguay. Vertebrate Zoology, 59(1): 3-9.

Bertaco, V. A. \& C. A. S. Lucena. 2006. Two new species of Astyanax (Ostariophysi: Characiformes: Characidae) from eastern Brazil with a synopsis of the Astyanax scabripinnis species complex. Neotropical Ichthyology, 4(1): 53-60.

Bertaco, V.A. \& L. R. Malabarba. 2001. Description of new species of Astyanax (Teleostei: Characidae) from headwater streams of Southern Brazil, with comments on the "A. scabripinnis species complex". Ichthyological Exploration of Freshwaters, 12(3): 221-234.

Bookstein F. L., B. Chernoff, R. L. Elder, J. M. Humphries, G. R. Smith \& R. E. Strauss. 1985. Morphometrics in evolutionary biology: The geometry of size and shape change with examples from fishes. The Academy of National Sciences of Philadelphia, Philadelphia, Special Publication, (15): 1-277.

Burns, J. R. \& S. H. Weitzman. 1996. Novel gill-derived gland in the male swordtail characin, Corynopoma riisei (Teleostei: Characidae: Glandulocaudinae). Copeia, 1996(3): 627-633.

Castro, R. M. C. \& R. P. Vari. 2004. Astyanax biotae, a new species of stream fish from the Rio Paranapanema basin, upper Rio Paraná system, southeastern Brazil (Ostariophysi: Characiformes: Characidae). Proceedings of the Biological Society of Washington, 117(3): 330-338.

Cope, E. D. 1894. On the fishes obtained by the Naturalist Expedition in Rio Grande do Sul. Proceedings of the American Philosophical Society, 33: 84-108.

Eigenmann, C. H. 1910. Catalogue of fresh water fishes of tropical and South America. Reports of the Princeton University Expedition to Patagonia, 1896-1899, 3(4): 375-511.

Eigenmann, C. H. 1921. The American Characidae. Part 3. Memoirs of the Museum of Comparative Zoology, 43: 208-310.

Eigenmann, C. H. 1927. The American Characidae. Part 4. Memoirs of the Museum of Comparative Zoology, 43: 311-428.

Fink, W. L. \& S. H. Weitzman. 1974. The so-called cheirodontin fishes of Central America with descriptions of two new species (Pisces: Characidae). Smithsonian Contributions to Zoology, 172: 1-46.

Fowler, H. W. 1906. Further knowledge of some heterognathus fishes. Part I. Proceedings of the Academy of Natural Sciences of Philadelphia, 58: 293-351.

Garutti, V. 1995. Revisão taxonômica dos Astyanax (Pisces, Characidae) com uma mancha umeral ovalada e mancha no pedúnculo caudal, estendendo-se à extremidade dos raios caudais medianos, das bacias do Paraná, São Francisco e Amazônica. Unplublished Ph.D. Dissertation, Universidade Estadual Paulista, IBILCE-UNESP, São José do Rio Preto, 286p.

Haluch, C. F. \& V. Abilhoa. 2005. Astyanax totae, a new characid species (Teleostei: Characidae) from the upper rio Iguaçu basin, southeastern Brazil. Neotropical Ichthyology, 3(3): 374-383.

Hammer, O. \& D. A. T. Harper. 2003. Past version 1.8. Available from: http://folk.uio.no/ohammer/past (April/2009).

Hensel, R. 1870. Beiträge zur Kenntniss der Wirbelthiere Südbrasiliens. Fortsetzung. Archiv für Naturgeschichte, 36(1): 50-91.

Lima, F. C. T., L. R. Malabarba, P. A. Buckup, J. F. Pezzi da Silva, R. P. Vari, A. Harold, R. Benine, O. T. Oyakawa, C. S. Pavanelli, N. A. Menezes, C. A. S. Lucena, M. C. S. L. Malabarba, Z. M. S. Lucena, R. E. Reis, F. Langeani, L. Casatti, V. A. Bertaco, C.
Moreira \& P. H. F. Lucinda. 2003. Genera incertae sedis in Characidae. Pp. 106-169. In: Reis, R. E., S. O. Kullander \& C. J. Ferraris Jr. (Eds.). Check List of the Freshwater Fishes of South and Central America. Porto Alegre, Edipucrs, 729p.

Malabarba, L. R. 1989. Histórico sistemático e lista comentada das espécies de peixes de água doce do sistema da laguna dos Patos, Rio Grande do Sul, Brasil. Comunicações do Museu de Ciências e Tecnologia da PUCRS, Série Zoologia, 2(8): 107-179.

Malabarba, L. R. \& E. A. Isaia. 1992. The fresh water fish fauna of the rio Tramandaí drainage, Rio Grande do Sul, Brazil, with a discussion of its historical origin. Comunicações do Museu de Ciências e Tecnologia da PUCRS, Série Zoologia, 5(12): 197-223.

Melo, F. A. G. 2001. Revisão taxonômica das espécies do gênero Astyanax Baird \& Girard, 1854 (Teleostei: Characiformes: Characidae) da região da serra dos Órgãos. Arquivos do Museu Nacional, 59: 1-46.

Melo, F. A. G. \& P. A. Buckup. 2006. Astyanax henseli, a new name for Tetragonopterus aeneus Hensel, 1870 from southern Brazil (Teleostei: Characiformes). Neotropical Ichthyology, 4(1): 45-52.

Menezes, N. A. \& S. H. Weitzman. 1990. Two new species of Mimagoniates (Teleostei: Characidae: Glandulocaudinae), their phylogeny and biogeography and a key to the glandulocaudin fishes of Brazil and Paraguay. Proceedings of the Biological Society of Washington, 103(2): 380-426.

Menezes, N. A. \& S. H. Weitzman. 2009. Systematics of the Neotropical fish subfamily Glandulocaudinae (Teleostei: Characiformes: Characidae). Neotropical Ichthyology, 7(3): 295-370.

Miquelarena, A. M. \& R. C. Menni. 2005. Astyanax tumbayaensis, a new species from northwestern Argentina highlands (Characiformes: Characidae) with a key to the Argentinean species of the genus and comments on their distribution. Revue Suisse de Zoologie, 112(3): 661-676.

Moreira-Filho, O. \& L. A. C. Bertollo. 1991. Astyanax scabripinnis (Pisces, Characidae): a species complex. Revista Brasileira de Genética, 14: 331-357.

Rosa, R., M. Rubert, L. R. Malabarba, I. C. Martins-Santos \& L. Giuliano-Caetano. 2009. Cytogenetic analysis of Astyanax laticeps (Cope, 1894) (Ostariophysi: Characidae) from the laguna dos Patos system. Neotropical Ichthyology, 7(4): 601-605.

Steindachner, F. 1876. Die Süsswasserfische des südöstlichen Brasilien (III). Sitzungsberichte der Kaiserlichen Akademie der Wissenschaften, 74: 559-694.

Taylor, W. R. \& G. C. van Dyke. 1985. Revised procedures for staining and clearing small fishes and other vertebrates for bone and cartilage study. Cybium, 9: 107-119.

Villela, F. S., F. G. Becker \& S. M. Hartz. 2002. Diet of Astyanax species (Teleostei, Characidae) in an Atlantic Forest River in Southern Brazil. Brazilian Archives of Biology and Technology, 45(2): 223-232.

Weitzman, S. H. \& L. R. Malabarba. 1999. Systematics of Spintherobolus (Teleostei: Characidae: Cheirodontinae) from eastern Brazil. Ichthyological Exploration of Freshwaters, 10(1): 1-43.

Weitzman, S. H., N. A. Menezes \& M. J. Weitzman. 1988. Phylogenetic biogeography of the Glandulocaudini (Teleostei: Characiformes, Characidae) with comments on the distributions of other freshwater fishes in eastern and southeastern Brazil. Pp. 379-427. In: Vanzolini, P. E. \& W. R. Heyer (Eds.). Proceedings of a workshop on Neotropical distribution patterns. Rio de Janeiro. Academia Brasileira de Ciências, 488 p.

Accepted December 7, 2009 Published March 31, 2010 